\title{
Defence Spending, Institutional Environment and Economic Growth: Case of NATO*
}

\author{
Natalia Utrero-González† Jana Hromcová ${ }^{\ddagger}$ and Francisco J. Callado-Muñoz ${ }^{\S}$
}

October 2017

\begin{abstract}
This paper analyses the impact of participating in a military alliance on the nexus between defence spending and economic growth. In particular, we study how the process of gradual association to a military organization influences the defence spending of newcomers, and consequently their economic growth. Conclusions from the theoretical model are tested empirically for countries in the North Atlantic Treaty Organization. Results show that the prospect of intensified military alliance partnership and membership has a positive effect on economic growth. In addition, increased security and stability gained by closer military cooperation reinforces the positive link with economic growth. Empirical evidence supports theoretical priors.
\end{abstract}

Keywords: military alliance; defence spending; public spending; growth.

JEL classification: D74, H5, O4.

\footnotetext{
${ }^{*}$ We are grateful to Mohamed Douch, two anonymous referees, participants at 11th Defence and Security Economics Workshop in Carleton University and 21st Conference on Economics and Security for helpful suggestions and comments. Financial support from the Ministry of Education and Science through grants ECO2013-45395-R, ECO2013-48496-C4-4-R, ECO2015-67999-R (MINECO/FEDER), ECO2016-76255-P, the Regional Government of Aragón and the European Social Fund (S125 project: Compete), and the Centro Universitario de la Defensa Zaragoza through the 2016-06 project is gratefully acknowledged.

${ }^{\dagger}$ Centro Universitario de la Defensa de Zaragoza, Academia General Militar. Ctra. de Huesca s/n, 50090 Zaragoza, Spain; Tel: +34 97673 9877; Fax: 976739 824; n.utrero@unizar.es

${ }^{\ddagger}$ Universitat Autònoma de Barcelona, Departament d’Economia Aplicada, Edifici B, 08193 Bellaterra, Barcelona, Spain; Tel: +34-93 581 4579; Fax: +34-93 581 2292; jana.hromcova@uab.cat

${ }^{\S}$ Centro Universitario de la Defensa de Zaragoza, Academia General Militar. Ctra. de Huesca s/n, 50090 Zaragoza, Spain; Tel: +34 97673 9804; Fax: 976739 824; fcallado@unizar.es
} 


\section{Introduction}

The relationship between defence spending and economic growth has been widely studied in the literature, both from theoretical and empirical points of view (Dunne et al., 2005). Results are inconclusive and many of the traditional empirical studies find that military spending is not a significant factor in explaining economic growth (d'Agostino et al., 2017). The usual explanation is that defence spending is not productive, in contrast to investment in infrastructure, research and development, or education, and does not affect output directly (Korkmaz, 2015). However, conflicts and lack of security are considered as obstacles to economic development (Töngür and Elveren, 2012). Security of population and private property is essential for good functioning of markets and also promote investment and innovation. Defence spending provides security against internal and external threats inducing positive externalities for the military spending and growth relationship (Musayev, 2013). Furthermore, the effects of a nation's defence spending on growth could be affected by the level of development (Alptekin and Levine, 2012), the defence expenditure of neighbour nations or alliance membership (Macnair et al., 1995).

The economic theory of alliances focuses on burden sharing, in which the large, rich ally shoulders the defence burden of the small, poor allies by providing the latter with a relatively free ride (Olson, 1965 and Olson and Zeckhauser, 1966). Yet, alliances can be more than aggregations of military power: explicit set of rules that prescribe behavioural roles and constraint activity (Wallander, 2000). Actually, formal alliances are social institutions that involve extensive interactions. They produce subsidiary agreements which are likely to exert a more lasting influence on the attitudes and behaviour of each member (Walt, 1997) and may survive the threats that had given rise to them (Kim, 2015). Accordingly, defence alliances have increasingly turned to peacekeeping and peace enforcement with the end of the Cold War, requiring a degree of integration and cooperation never experienced before. This new scenario has renewed the interest on military institutions (Sandler and Hartley, 2001) and its implications not only for defence burden sharing but also for alliance institutional design and stability.

La Porta et al. (1997) show the important role of institutional environment and regulations on the behaviour of economic agents. Their work implies that the existence of a solid and reliable institutional environment can boost countries's economic growth. Supranational legislation may serve as a further impulse to accelerate investment and technological development. In this line, Callado et al. (2016) show how a participation in an economic and monetary union grants an institutional stimulus for additional technological development of newcomers. Moreover, in an increasingly globalised world, growth rates of individual countries do not only depend on their own characteristics, such as defence spending or infrastructure, but they seem to be critically related to the income levels and growth rates of their trading partners, usually their neighbouring countries (Klenow and Rodriguez-Clare, 2005). In this regard, Callado et al. (2013) show that developing countries may benefit from free trade agreements with developed ones by gradually adopting their more developed financial systems and consequently improve the performance of their economies. With respect to defence, formal alliances, as the North Atlantic Treaty Organization (NATO), have the potential to promote common defence, development of new technologies and capabilities to adapt to the new strategic environment (Ruíz, 2014). 
The existence of a sound and reliable institutional environment could clearly increase security. However, the effect of the integration into a military institution on the economy has not been studied within the defence spending - economic growth relationship. We attempt to make a contribution in this line.

This paper analyses how the integration into a military alliance and the influence of the military institutional agreements and the new military status can affect the relationship between defence spending and economic growth. To set up a theoretical model in the context of a military institution we introduce the membership in a military alliance into the models of Shieh (2002) and Pieroni (2009). If a country chooses to integrate into a military alliance, common defence policy insures higher level of security. This should be beneficial for the economic stability and consequently for growth. On the other hand, membership in a military institution may affect the defence spending of all alliance components, and thereupon the output of all parties involved. This effect may have a negative impact under certain conditions. In the empirical part we study the case of the North Atlantic Treaty Organization (NATO). NATO was born at the outset of the Cold War, designed to meet three complementary objectives: deter Soviet expansionism, prevent the revival of nationalist militarism in Europe through a strong North American presence at the continent, and encourage European political integration. Although its core function lay in the collective defence of Central and Western Europe against a Soviet attack, the alliance was also intended to build peace and security among its members as democratic countries (Kugler, 1998). Along the Cold War, NATO developed procedures and mechanisms to implement its military policy that proved to be useful for a broad range of missions beyond deterrence and defence and allow the alliance to adapt to a new security environment after the Cold War (Wallander, 2000).

The end of the Cold War and the disintegration of the Soviet Union forced NATO and its member states to adapt. The military dimension lost its previous dominance to international cooperation and aid (Chalmers, 2001). This evolution has affected NATO's membership and its role in the developing of new partnerships with other countries. This enlargement process is a natural experiment that allows us to analyse how the process of entering a military alliance (considering both the role of new military institutions together with the security benefits from that integration) may impact economic growth.

The remainder of the paper is organised as follows. In section 2 we outline some information about NATO related to our research. Section 3 presents the theoretical model. Empirical analysis is performed in section 4. Relationships obtained in the empirical exercise are discussed in section 5. Final remarks are summarised in section 6.

\section{North Atlantic Treaty Organization}

An alliance is a formal or informal commitment for security cooperation between two or more states (Walt, 1997). NATO was established trough the Washington Treaty in 1949. Its main mission was to build peace and security among its members as democratic countries (Wallander, 2000). From the very beginning, the alliance had a double commitment as stated in article 4 (peace and security) and article 5 (collective defence). 
This double objective along with the development of formal decision-making procedures, subsidiary agreements and supporting bureaucracy has led NATO to become a social institution that involves extensive interactions between member-states and partner countries (Walt, 1997). These political mechanisms and institutional building have proven useful in different circumstances such as civil emergency planning or science cooperation. They allow to decide how to address them and to implement decisions once they had been made (Wallander, 2000) and they help to explain NATO endurance and enlargement in the aftermath of the Cold War. NATO has become a global institution committed to adapt structures to today's environment to better comply its mission and maximise efficiency (Lisbon Summit, 2010). ${ }^{1}$

The enlargement of the Alliance is an ongoing and dynamic process. Since the Alliance was created in 1949, its membership has grown from the 12 founding members to today's 28 members through six rounds of enlargement in 1952, 1955, 1982, 1999, 2004 and 2009. The first three rounds of enlargement - which brought in Greece and Turkey (1952), West Germany (1955) and Spain (1982) - took place during the Cold War, when strategic considerations were at the forefront of decision-making.

The fall of the Berlin Wall in November 1989 signalled the end of the Cold War and was followed by the dissolution of the Warsaw Pact and the breakup of the Soviet Union. The reunification of Germany in October 1990 brought the territory of the former East Germany into the Alliance. The new democracies of Central and Eastern Europe were eager to guarantee their freedom by becoming integrated into Euro-Atlantic institutions. In this scenario NATO adopted a new strategic doctrine that calls for crisis management and peace enforcement in places even outside of Europe whenever NATO's vital interests could be at risk. This new strategy inspired the enlargement process and the development of structured partnerships.

The Czech Republic, Hungary and Poland were the first former members of the Warsaw Pact to join NATO in 1999. At the same time, the Alliance designed an institutional framework to become a member. Namely, the Membership Action Plan (MAP) was launched. The first step to become a member of NATO is to declare an interest in joining the alliance. Countries are invited to engage in an intensified political dialogue with NATO about their membership aspirations and related reforms. Aspirant countries may then be invited to participate in the Membership Action Plan (MAP) to prepare and demonstrate their ability to meet obligations and commitments of future membership. MAP is reviewed every year by the Annual National Plan.

Countries seeking NATO membership would have to be able to demonstrate that they have fulfilled the following requirements: i) a functioning democratic political system based on a market economy, ii) the fair treatment of minority populations, iii) a commitment to the peaceful resolution of conflicts, iv) the ability and willingness to make a military contribution to NATO operations and v) a commitment to democratic civil-military relations and institutional structures. Once admitted, new members would enjoy all the rights and assume all the obligations of membership. This would include acceptance, at the time when they join, of all the principles, policies and procedures previously adopted by Alliance members (NATO, 2015a). Among them, standardization agreements play an important role (STANAG). Member states need to

\footnotetext{
${ }^{1}$ Adaptation is made through continual reform of both structures and working methods.
} 
share a common set of standards, especially among military forces, to carry out multinational operations. In particular, NATO standardization is the development and implementation of concepts, doctrines and procedures to achieve and maintain the required levels of compatibility, interchangeability or commonality needed to achieve interoperability. Standardization affects the operational, procedural, material and administrative fields. This standardization allows for more efficient use of resources and thus enhances the Alliance's operational effectiveness (NATO, 2015b). Bulgaria, Estonia, Latvia, Lithuania, Romania, Slovakia and Slovenia which joined NATO in 2004 conform the fifth round of enlargement. All seven countries had participated in the MAP.

Along with these enlargement rounds, NATO has developed a number of partnership tools and mechanisms to support cooperation with partner countries through a mix of policies, programmes, action plans and other arrangements. Many tools are focused on the important priorities of interoperability and building capabilities, and supporting defence and securityrelated reform. Partnerships with countries from the Euro-Atlantic area, the Mediterranean, Gulf region, as well as individual relationships with other partners such as Japan or Australia have been developed and adapted to the new defence and security challenges. Yet, relations with North-Atlantic countries continue to be more intense.

Accordingly, the Partnership for Peace program (PfP) was established in 1994. The purpose of the Partnership for Peace was to increase stability, diminish threats to peace and build strengthened security relationships between NATO and non-member countries in the EuroAtlantic area based on a commitment to democratic principles. The PfP enabled participants to develop an individual relationship with NATO, choosing their own priorities for cooperation, and the level and pace of progress. In 1995 the PfP Planning and Review Process (PARP) was launched to enhance interoperability and capabilities of partner forces that could be made available to the Alliance for multinational training, exercises and operations. The PARP also served as a planning tool to guide and measure progress in defence and military transformation and modernisation efforts. Countries that wish to join NATO must participate in the PARP as a pre-requisite to join the Membership Action Plan (MAP).

Moreover, Individual Partnership Action Plans (IPAPs) are open to countries that have the political will and ability to deepen their relationship with NATO. Partners periodically review their IPAPs and eventually move from this mechanism to the MAP through the development of Annual National Programmes.

Over time, the PARP has developed in several ways in order to serve different purposes. Following the review of NATO's partnerships policy in April 2011, participation was also opened to all other partners on a voluntary and case-by-case basis. In addition to improving interoperability and increasing transparency, the Alliance also uses the PARP to support reform efforts.

Along this period, all partners have increased relationships with NATO in a very broad range of security-related areas and can participate in over 1,000 activities offered in the Partnership Cooperation Menu pursuing a high level of cooperation with NATO in particular in the area of defence reform and capacity building.

There has been debate about NATO enlargement and whether it is prudent (Murdoch and Sandler, 2000). Yet, as NATO transforms (through enlargement and partnership building) and 
evolves to meet the new security challenges, it continues to be central of the new security and economic architecture in the Atlantic relationship (Mattox, 1998). Moreover, NATO's enlargement efforts run parallel and complementary to other institutional organizations' enlargements. For this reason, expanding NATO seems an appropriate and cost effective approach for accomplishing the new strategic objectives (Funk, 1998). The variety of issues with which it has engaged has grown significantly and its military structures have been thoroughly reformed, much has also persisted (Weber et al., 2012). Not without the logical difficulties from the enlarged organization, NATO has the leverage and the means of influence to help coordinate the members and partners states' choices and to assist countries in working toward optimal use of their resources and capabilities (Szayna, 2001).

Figure 1 displays the countries included in the sample and the evolution of their relationship with the alliance.

[insert Figure 1 here]

Partners contribute in many ways to shaping discussions and debates in the Alliance. However, only members make decisions and recommendations which are based on consensus (NATO, 2014). The costs of running NATO are paid by member countries who make direct and indirect contributions to develop and implement its policies and activities. Free riding is of course possible, as also suggested by numerous works, i.e. Olson and Zeckhauser (1966) or Sandler and Murdoch (2000), but the additional accords between countries should push it to the minimum. NATO's 2014 Wales agreement (NATO, 2017) may be one example of such a debate. Members contribute according to an agreed cost-share formula. Even the $2 \%$ defence investment guideline is not binding, countries agreed upon maintaining their military spending to GDP at this given level or move towards the target. The emphasis on the $2 \%$ target should help to reduce the traditional imbalance of NATO budget. At the same time, NATO security guarantee does not mean that individual countries have no responsibility in their own self defence (Mattelaer, 2016). Moreover, as various countries belong to different institutional organizations, there is an additional space for bargaining over the burden sharing, in particular some countries might be among big contributors in one organization, and less so in another one. This could be the case of European Union. Actually NATO and European Union (EU) have 22 member countries in common, share similar values and interests and have developed a close strategic relationship along the years. EU has been suggested to free-ride on its military protection (Chalmers, 2001) and this behaviour could affect NATO's future arrangements and evolution. However, Becker (2017) shows that non-NATO allies in EU are as prone to free-riding as are allies - rather than being the source of a free-riding problem, the institutional components of NATO may provide a forum to make decisions to address such problems. Furthermore, with the end of the Cold war there has been a general significant downsizing of defence budgets among most NATO allies and partners with the exception of Greece and Turkey although there is no evidence of disproportionate burden sharing (at least during the nineties), Sandler and Murdoch (2000). We can observe the evolution of the average defence spending to GDP in founding countries, new members and partners in Figure 2A. The three groups present a decreasing trend along the whole period of analysis. Both the average and the evolution, are especially similar from 
1993 on with the end of the cold war. Figure 2B includes the evolution of new members by entry date. Again, the evolution of defence spending does not change much due to alliance membership.

[insert Figure 2 here]

\section{Theoretical Model}

As stated before, we are interested in the effect that a military alliance partnership and membership has on growth. Alliance partnership, and in particular, alliance membership should come along with relevant benefits of common security. If no relationship is established, the total amount of military spending is determined by own funds devoted by each individual country. If a country is somehow associated to an alliance, such as NATO, military spending will be affected by the rules, procedures and structure of the alliance that will merge their resources and military know-how together with the ones provided by each country. ${ }^{2}$

Let us consider an economy populated by infinitely lived identical households. Households maximise their discounted utility function over the stream of consumption $c_{t}$ and security (national defence) $s_{t}$

$$
\sum_{t=0}^{\infty} \beta^{t}\left[\frac{c_{t}^{1-\theta}-1}{1-\theta}+\psi S\left(s_{t}\right)\right]
$$

where $0<\beta<1$ is the discount factor, $\theta>0$ is the inverse of the elasticity of intertemporal substitution, $\psi$ is the weight agents assign to national security and the function $S(\cdot)$ is increasing in security.

Government spending $g_{t}$ is productive, as in Barro (1990). We assume the production function to have the Cobb-Douglass form, similar to Pieroni (2009),

$$
y_{t}=A_{t} k_{t}^{1-\varepsilon-\sigma} n_{t}^{\varepsilon}\left(m_{t}^{1-\kappa} M_{t}^{\kappa}\right)^{\sigma}
$$

where $y_{t}$ is output per capita at time $t, A_{t}$ is the productivity level at time $t, k_{t}$ is the physical capital per capita, $n_{t}$ is non-military spending per capita, $m_{t}$ is military spending per capita and $M_{t}$ is the total alliance military spending per total of the alliance inhabitants (it provides the measure of military spending of all countries involved in the relation). The elasticities of output with respect to non-military spending and military spending are $\varepsilon$ and $\sigma, 0<\varepsilon<1,0<\sigma<1$, respectively. Parameter $\kappa, 0<\kappa<1$, characterizes the weight the alliance military spending has in the national production, i.e. the spillovers from the alliance membership. ${ }^{3}$

\footnotetext{
${ }^{2}$ It is considered that alliance membership would mean a standardisation of military spending to comply with the norms laid down by the alliance. For example, the NATO Connected Forces Initiative that combines a comprehensive education, training, exercise and evaluation program with the use of cutting-edge technology to enhance the high level of interconnectedness and ensure that Allied forces remain prepared to engage cooperatively in the future.

${ }^{3}$ Total military spending per capita $M_{t}$ is an externality in the production function as agents do not take into account that a change in their military spending $m_{t}$ affects the total spending. The social planner solution will have to take that effect into account.
} 
Government spending $g_{t}$ is considered to take two forms: military spending, $m_{t}$ and nonmilitary spending, $n_{t}$. In each period a fraction $\rho_{t}$ of government spending is devoted to the military spending

$$
m_{t}=\rho_{t} g_{t}
$$

and the rest to the non-military one

$$
n_{t}=\left(1-\rho_{t}\right) g_{t}
$$

Military spending is necessary for providing security. Higher security increases agents' welfare. Security is further enhanced by military alliance membership. Production of national security is specified as

$$
s_{t}=B_{t} \mathbb{M}_{t}
$$

where $B_{t}$ is the efficiency at which military spending is turned into national security and $\mathbb{M}_{t}$ is the total alliance military spending per capita in the analyzed economy. ${ }^{4,5}$ If a country becomes involved in a relationship with the alliance, its military spending may be modified. The following expression reflects convergence to the 'standard' level of military spending

$$
m_{t+1}=\left(\gamma^{*}-1\right)\left[(1-\pi) m_{t}+\pi M_{t}\right]+m_{t}
$$

where $\gamma^{*}$ is the balanced growth path growth rate of our economy, $\pi, 0<\pi<1$, measures the speed of convergence. In this case the fraction of government spending which goes to military spending may be affected by the relationship with the alliance

$$
\rho_{t}=\rho\left(m_{t}, M_{t}\right) \text {. }
$$

Government finances its spending by taxing output at a rate $\tau_{t}$

$$
g_{t}=\tau_{t} A_{t} k_{t}^{1-\varepsilon-\sigma} n_{t}^{\varepsilon}\left(m_{t}^{1-\kappa} M_{t}^{\kappa}\right)^{\sigma} .
$$

Households enter a given period with capital $k_{t}$. They distribute their income between consumption $c_{t}$ and investment $i_{t}$. Capital depreciates at a rate $\delta$ and investment is given by

$$
i_{t}=k_{t+1}-(1-\delta) k_{t} \text {. }
$$

Households spend their disposable income on consumption and investment, and their budget constraint can be written as

$$
c_{t}+k_{t+1}-(1-\delta) k_{t}=\left(1-\tau_{t}\right) A_{t} k_{t}^{1-\varepsilon-\sigma} n_{t}^{\varepsilon}\left(m_{t}^{1-\kappa} M_{t}^{\kappa}\right)^{\sigma} .
$$

\footnotetext{
${ }^{4}$ The total alliance military spending may be represented by the stock of arms available in the whole alliance. If a country has low number of inhabitants the available stock of arms will be large. This reflects the fact that a small country will benefit more from alliance membership in case of a conflict: according to one of the strategic links, NATO members will always assist each other against attacks (NATO, 2010).

${ }^{5}$ Notice the difference between $\mathbb{M}_{t}$ (total alliance military spending per capita in the analyzed country), $M_{t}$ (total alliance military spending per all alliance inhabitants) and $m_{t}$ (military spending per capita in the analyzed country).
} 
The ratio of government spending to physical capital can be expressed from (3) as

$$
\frac{g_{t}}{k_{t}}=\left(\tau_{t} A_{t}\right)^{\frac{1}{1-\varepsilon-(1-\kappa) \sigma}}\left(1-\rho_{t}\right)^{\frac{\varepsilon}{1-\varepsilon-(1-\kappa) \sigma}} \rho_{t}^{\frac{\sigma}{1-\varepsilon-(1-\kappa) \sigma}}\left(\frac{M_{t}}{k_{t}}\right)^{\frac{\kappa \sigma}{1-\varepsilon-(1-\kappa) \sigma}} .
$$

Maximising the household utility (1) with respect to the budget constraint (4), using (5), we get the following expression for the growth rate of consumption

$$
\begin{aligned}
\gamma_{t}= & \frac{c_{t+1}}{c_{t}}=\left\{\beta \left[(1-\varepsilon-\sigma)\left(1-\tau_{t+1}\right) \tau_{t+1}^{\frac{\varepsilon+\sigma}{1-\varepsilon(1-\kappa) \sigma}} A_{t+1}^{\frac{1}{1-\varepsilon-(1-\kappa) \sigma}}\right.\right. \\
& \left.\left.\left(1-\rho_{t+1}\right)^{\frac{\varepsilon}{1-\varepsilon-(1-\kappa) \sigma}}\left(\rho_{t+1}\right)^{\frac{\sigma}{1-\varepsilon-(1-\kappa) \sigma}}\left(\frac{M_{t}}{k_{t}}\right)^{\frac{\kappa \sigma}{1-\varepsilon-(1-\kappa) \sigma}}+1-\delta\right]\right\}^{\frac{1}{\theta}} .
\end{aligned}
$$

Using the households' budget constraint (4) and the government budget constraint (3) we know that the growth rate of all variables is the same. ${ }^{6}$ If the tax rate is constant, $\tau_{t}=\tau$, the fraction of government spending devoted to military spending is also constant, $\rho_{t}=\rho$, the whole model collapses to an AK model, as developed in Barro (1990). In that case the growth rate is maximised when the tax rate is set to

$$
\tau^{\max }=\varepsilon+\sigma
$$

and the fraction of government spending destined to military spending is

$$
\rho^{\max }=\frac{(1-\kappa) \sigma}{\varepsilon+(1-\kappa) \sigma} .
$$

This implies that the fraction of military spending in gross domestic product (GDP) that maximises the growth rate is

$$
\left(\frac{m_{t}}{y_{t}}\right)^{\max }=\tau^{\max } \rho^{\max }=(1-\kappa) \sigma .
$$

If NATO members are encouraged to converge in their military spending to a given fraction of their GDPs, we can predict the effects by taking into account their structural parameters. ${ }^{7}$

Notice that if we rewrite slightly the production function we can observe that the ratio $\frac{M_{t}}{m_{t}}$ is an external effect the military alliance has on the economy

$$
y_{t}=A_{t} k_{t}^{1-\varepsilon-\sigma} n_{t}^{\varepsilon} m_{t}^{\sigma}\left(\frac{M_{t}}{m_{t}}\right)^{\kappa \sigma} \text {. }
$$

\footnotetext{
${ }^{6}$ Given the convergence equation (2), once $m_{t}$ converges to $M_{t}$, the external effect will disappear and the model collapses to Pieroni (2009).

${ }^{7}$ Function $\tau=T(\gamma), \rho=R(\gamma)$ are both concave, i.e.

$$
\begin{aligned}
& \frac{d \tau}{d \gamma}>0 \text { for } \tau<\tau^{\max }, \frac{d \tau}{d \gamma}<0 \text { for } \tau>\tau^{\max }, \\
& \frac{d \rho}{d \gamma}>0 \text { for } \rho<\rho^{\max }, \frac{d \rho}{d \gamma}<0 \text { for } \rho>\rho^{\max } .
\end{aligned}
$$
}


The more the national military spending lags behind the alliance one, the stronger should be the alliance pull. Rewriting the growth rate using the relative military spending we get

$$
\begin{aligned}
\gamma_{t}= & \left\{\beta \left[(1-\varepsilon-\sigma)\left(1-\tau_{t+1}\right) \tau_{t+1}^{\frac{\varepsilon+\sigma}{1-\varepsilon-\sigma}} A_{t+1}^{\frac{1}{1-\varepsilon-\sigma}}\right.\right. \\
& \left.\left.\left(1-\rho_{t+1}\right)^{\frac{\varepsilon}{1-\varepsilon-\sigma}}\left(\rho_{t+1}\right)^{\frac{\sigma+(\varepsilon+\sigma) \kappa \sigma}{1-\varepsilon-\sigma}}\left(\frac{M_{t+1}}{m_{t+1}}\right)^{\frac{\kappa \sigma(\varepsilon+\sigma)}{1-\varepsilon-\sigma}}+1-\delta\right]\right\}^{\frac{1}{\theta}} .
\end{aligned}
$$

The growth rate of consumption can thus be expressed as a function of the external effect, tax rate, fraction of government spending devoted to non-military and military spending and the structural parameters of the economy.

Setting $\kappa=0$ we get a version of the model of Pieroni (2009), a model for a country which is not a member of an alliance. In this case the national security would be just a function of national military spending

$$
s_{t}^{\text {non-member }}=B_{t} m_{t}
$$

In the model, military spending is necessary to provide security, but it also contributes to output. Therefore, countries have double incentive to devote resources to military spending. The ones affiliated to an alliance have an agreement to converge to a chosen ratio of military spending to GDP, thus they will adjust to that path over time. Some countries will increase the military spending to GDP as the convergence goal is above their initial level, some others will decrease it. This will have an effect on the total military spending per capita in the transition. Once the balanced growth path is reached, they should keep the agreed military spending to GDP target.

\subsection{Equilibrium behaviour}

We have two effects playing against each other in this model. The military alliance membership and the compliance increases the fraction of government spending devoted to military spending, $\rho_{t}$. If $\rho^{\max }$ and $\tau^{\max }$ were employed before the country becomes a member of a military alliance, the convergence to the required standards would induce negative effect on growth. On the other hand, the military alliance membership provides higher security and stability. This positive effect on growth is expressed as a spillover in the production function.

\section{Empirical Analysis}

\subsection{Data and Methodology}

According to the conclusions of the model, the relationship between defence spending and economic growth would be affected by belonging to a military alliance and the commitments linked to membership. Further, the model suggests a positive effect associated to the increased efficiency related to security and stability and a negative effect provided the defence spending 
increases above the optimal level due to alliance commitments, being this effect larger the more the country lags behind. Following equation (8) of the model, the growth rate of the economy will depend on military spending and its relationship with the rest of the public expenditure, on the fact of belonging or not to a military alliance and the effects it may have on the efficiency of the defence sector. The initial analysis is based on a dynamic panel data set of 64 countries over the 1950-2014 period. All the countries included are involved in one of the relationships with NATO, described in section 2, along the period of study. Similar to previous papers on defence spending and economic growth such as Yakovlev (2007), Compton and Paterson (2016) and Musayev (2016), we construct non-overlapping intervals to analyse the effects of military spending on growth which reduce biases stemming from reverse causation (Beck, 2008). In particular, we use three-year intervals. This procedure has the advantage that short-run cyclical fluctuations can be filtered out as well (Clements et al., 2003 and Aghion et al., 2009) and time horizon is not too much reduced. Similarly, Presbitero (2006) and Di Liberto et al. (2008) among others, have used this three-year interval approach. Accordingly, there are twenty two intervals in the period analysed. Therefore, the baseline specification to estimate is

$$
\Delta \mathrm{Y}_{i t}=\alpha_{0}+\alpha_{1} \text { GDPcap }_{i t-1}+\alpha_{2} \text { Nonmil }_{i t}+\alpha_{3} \text { Mil }_{i t}+\alpha_{4} \text { Alliance }_{i t}+\lambda \mathrm{X}_{i t}+\eta_{t}+\xi_{i t}
$$

where for country $i$ and period $t, \Delta \mathrm{Y}_{i t}$ is the three-year average log difference of real GDP, GDPcap $_{i t-1}$ is the logarithm of real GDP per capita at the beginning of the period, Nonmil $l_{i t}$ is the logarithm of non-military spending (government consumption and investment) to GDP, $\eta_{t}$ are country fixed effects and $\xi_{i t}$ is the error term.

Variable $\mathrm{Mil}_{i t}$ accounts for military expenditure. The baseline measure is computed as the three-year average of the logarithm of military spending to GDP and per capita military expenditure as an alternative one. Variable $\mathrm{X}_{i t}$ accounts for control variables traditionally used in the literature: population growth (PopGrowth) and education (Schooling), measured at the beginning of the period. Economic variables and population data come from the Penn World Tables (PWT) 9.0. Defence spending comes from Stockholm International Peace Research Institute (SIPRI) database and education, measured as the average years of schooling attained by total population aged 15 and over, come from Barro and Lee (2013). Variable Alliance ${ }_{i t}$ accounts for the effects associated to the relationship with the military alliance. Three different measures are introduced, namely NATO, NATO_benefit and NATO_partner benefit.

As explained above, the integration into NATO can be interpreted as a continuous process that has different phases: from the Dialogue phase to the implementation of the Membership Action Plan and the membership status. In each phase, countries are supposed to increase their partnership commitment with the alliance and approach NATO institutional arrangements and military procedures. ${ }^{8}$ Along the analysed period many countries have decided to become members while others have just reinforced their relationships. Accordingly, NATO variable is defined to capture the different country evolution and relation to NATO. It has the lowest values in early stages of relationships (Dialogue) and the largest value when membership is granted (ranging

\footnotetext{
${ }^{8}$ As stated above standarization allows for more efficient use of resources and thus enhances NATO's operational effectiveness.
} 
from 0 to 1). It represents the institutional arrangements/military procedures accepted in the relation with the alliance. Variable NATO_benefit, instead, is a proxy for the security benefits associated to the common defence spending and the collective action established in NATO treaty. For country $i$, we compute the ratio between the NATO per capita defence spending and the national per capita defence spending. ${ }^{9}$ Values greater than 1 indicate that country $i$ is benefiting from NATO membership because its national defence expenditure is lower than the average alliance expenditure. Additionally, we define NATO_partner benefit to account for the security benefits linked to partnership, that is, it proxies the profit the partner nation would be able to obtain with lesser commitments than members. It is calculated in a similar fashion as NATO_benefit, including partner countries as well. As before, values greater than 1 indicate that country $i$ enjoys larger benefits from NATO partnership. Both variables NATO_benefit and NATO_partner benefit take into account the different NATO members/partners in each period. Furthermore, during our period of analysis there have been important changes in the international strategic scenario which have conditioned NATO evolution and doctrinal change. NATO defines seven different key events that have shaped these changes. ${ }^{10}$ Accordingly, seven dummy variables are defined to control for these circumstances and introduced in the regression analysis. Table 1 collects summary statistics of the data used.

[insert Table 1 here]

We estimate equation (9) using system GMM dynamic panel data estimator. Traditionally GMM uses first-difference transformation. However, this technique has a weakness. It magnifies gaps in unbalanced panels (Roodman, 2009). Arellano and Bover (1995) propose a second transformation 'orthogonal deviations' that minimizes data loss and since lagged observations do not enter the formula, they are valid as instruments. Since the sample is small, we decide to use this transformation in order to preserve sample size. Further, to avoid over-fitting, we collapse the instrument matrix. ${ }^{11,12}$ From the time series analysis point of view some problems

${ }^{9}$ Variable NATO_benefit is computed as

$$
\text { NATO_benefit } t=\frac{\frac{\sum_{j=1}^{N_{t}} \text { defence spending }_{j t}}{\sum_{j=1}^{N_{t}} \text { population }_{j t}}}{\frac{\text { defence spending }_{i t}}{\text { population }_{i t}}}
$$

where $i$ stands for the country in question, $j=1, \ldots, i, \ldots N_{t}$, and $N_{t}$ is the number of members and given time period $t$.

${ }^{10}$ These events correspond to: birth of NATO (1949), fall of the Berlin Wall (1989), NATO development of partnerships with former adversaries (1991), Bosnia-Herzegovina crisis (1995), terrorist attacks in New York and Washington (2001), NATO command of International Security Assistant Force in Afghanistan (2003 ), NATO adoption of "Active Engagement, Modern Defence" (2010).

${ }^{11}$ We have chosen not to run two-step GMM due to well-known finite sample problems associated with the standard errors of two-step estimates. Indeed, two-step estimates of the model (not reported) suggest significant downward bias in the standard errors, even after using the Windmeijer (2005) correction.

${ }^{12}$ All independent variables are treated as endogenous. 
may arise because data may be non-stationary. As a consequence, that would give rise to co-integration analysis and specification of an error-correction model. We perform a battery of panel unit root tests. ${ }^{13}$ Table A.1 in Appendix collects the results. Individual unit root processes are rejected for GDP per capita (GDPcap), GDP growth $(\Delta \mathrm{Y})$, defence spending over GDP (Mil) and NATO_partner benefit. Results are inconclusive for NATO and NATO_benefit and depend on the test performed. Therefore, we do not find evidence of non-stationarity in our sample.

\section{Results}

Table 2: Panel A shows estimation results of equation (9) with the baseline measure of military expenditure. Hansen's tests for all specifications indicate the validity of the set of instruments chosen and that they are exogenous.

[insert Table 2: Panel A around here]

Column 1 presents the baseline specification. Initial GDP (GDPcap $i t-1)$ has a negative and significant coefficient. This result is consistent with previous studies on economic growth and convergence. Investment coefficient is positive and significant as expected. Education (Schooling) and Population growth (PopGrowth) do not present significant effects in our sample. These results maintain in all specifications. Civilian government spending presents a negative coefficient, but it is only significant when NATO_partner benefit is included in the regression (columns 6-7).

Looking at the variable of interest, military spending is not significant in any of the runs. In column 2 variable NATO that accounts for the degree of intenseness of the relation with the alliance is introduced. It presents a positive and significant coefficient. Therefore, the prospect of becoming a NATO member or intensifying partnership has a positive effect on economic growth. It can be considered as a positive shock for modernising armed forces, increasing transparency and support reform to be more efficient. In columns 3 and 4 we introduce the benefit associated to security increase, being a NATO member or a NATO partner (NATO_benefit, NATO_partner benefit). Both variables have positive and significant coefficients suggesting that the increased security and stability associated with the relationship with the alliance promotes economic growth. This result suggests that countries could have greater economic welfare by making their defence spending more similar to alliance standards. In column 5 to 7 we introduce an interaction term between defence spending over GDP and NATO variables. Results for initial GDP and investment maintain. Now the coefficient of government consumption is negative and significant suggesting a detrimental effect on economic growth. NATO institutional variable coefficient continue to be positive and significant. However, the interaction term is negative and significant. Hence, the positive effect of belonging to NATO institutional arrangements

\footnotetext{
${ }^{13}$ The tests performed are the Im, Pesaran and Shin (IPS), Augmented Dickey-Fuller (ADF) and PhillipsPerron (PP). The number of lags is chosen such that the AIC for the regression is minimized. This process is done for each panel so that different panels may use different numbers of lags.
} 
and enjoying the possibility of collective action is less relevant in countries with higher national defence spending. This result is in line with model predictions of a differential effect according to national defence spending. The results for NATO_benefit and NATO_partner benefit are in the same line: the positive direct effect is smaller for countries with higher defence spending. Interestingly, for NATO_partner benefit direct effect and second order effect are larger and smaller respectively, which may suggest that the partners benefit from the increased security with fewer inputs. Looking at diagnostic tests, the over-identification tests support the specification chosen and regarding the tests of autocorrelation AR (1) and AR (2), the null hypothesis (of no autocorrelation) is accepted at 5\% for all runs. ${ }^{14}$ Evidence for the alternative measure of military spending is presented in Table 2: Panel B. Results maintain, suggesting that they are not affected by the military expenditure measure used.

[insert Table 2: Panel B around here]

Next, we analyse separately the effects of NATO in countries with high and low defence spending (see Table A.2 in the Appendix for a general classification). Results are presented in Table 3. Defence spending is not significant for high spenders as in the whole sample and Alliance variables do not significantly affect economic growth (columns 1 and 2). Further, the interaction term is only significant when we introduce the NATO_benefit variable presenting a negative coefficient (column 4). In general terms, results for this subsample are weaker than for the whole sample. Evidence for the countries with low defence spending is stronger. First, defence spending affects positively and significantly economic growth and so Alliance variables do. In this case, the interaction variable is not significant in any of the specifications. These results indicate nonlinearities in the defence and economic growth nexus as well as the relationship between belonging to a military alliance and growth. This result is in line with the conclusions of the model that suggests greater impact for those countries that lag behind defence spending.

[insert Table 3 around here]

\subsection{Robustness Analysis}

We have shown that results are not affected by alternative defence expenditures and Alliance variable definitions but are dependent on national defence spending level. As explained above, there is also evidence of a positive effect of defence spending associated to less developed countries (Alpekin and Levine, 2012). Further, results could be impacted by the conflicts in which countries are involved (Aizenman and Glick, 2006) or the fact that a country is closer to areas in conflict and the national institutional setting (Compton and Paterson, 2016). Finally, USA is considered to be the leader of the alliance and its current administration has complained about the poor commitment of their allies. Therefore, we run four additional checks. First, we

\footnotetext{
${ }^{14} \mathrm{P}$-values around 0.8 except for last column.
} 
divide the sample between more and less developed countries. Second, we introduce a control for the number of conflicts, a geographical control, as well as institutional variables, and finally we carry out the analysis without USA. ${ }^{15,16,17}$

Results for the separated analysis of developed and less developed countries are displayed in Table 4. As shown for the countries with higher defence spending, developed countries present mild results: defence spending is not significant and Alliance variables do not significantly affect economic growth (columns 1 and 2). Further, the interaction terms are not significant either. Interestingly, the convergence effect maintains and the education proxy spurs economic growth. Evidence for less developed countries is stronger. First, defence spending affects positively and significantly economic growth. This result is in line with the meta-analysis of Alpekin and Levine (2012). Further, being a NATO partner has positive effects on growth. However, the benefits of collective defence institutional agreement do not significantly affect economic growth. In this case, as with developed economies, interaction variable is not significant in any of the specifications.

\section{[insert Table 4 around here]}

Table 5: Panel A presents the results when the conflicts and geography are taken into account. Results are not affected by the inclusion of these new control variables. Table 5: Panel B collects the results with the inclusion of the institutional controls for the NATO variable. The general message is that the positive effect of NATO on growth maintains when institutional background is taken into account, therefore discarding the idea that NATO variable could be proxying for other institutional arrangements. ${ }^{18}$ Table 6 shows the effects when USA is taken out of the analysis. Conclusions mimic the ones presented for the whole sample suggesting that the results are not driven by USA. To end up with the robustness analysis we have repeated the analysis using five-year intervals as in similar studies on defence economic growth nexus with the correspondent reduction in the number of observations. Results are not altered either (Table 7).

[insert Table 5: Panel A and B around here] [insert Table 6 around here]

\footnotetext{
${ }^{15}$ Conflict data come from UCDP/PRIO Armed Conflict Dataset version 4-2009. The first release is described in Gleditsch et al. (2002).

${ }^{16}$ Geographical control groups countries into five geographical categories. To construct this control we take into account the number of conflicts (similar to the region variable in the UCDP/PRIO conflict database) and the relationships with NATO. The categories are region 0 (Europe), region 1 (America), region 2 (Australia), region 3 (Asia) and region 4 (Africa).

${ }^{17}$ We introduce nine different measures of institutions from different sources. From the World Bank Database of Political Institutions we use System (whether the political system is parlamentary, assembly elected president or presidential), Checks (account for checks and balances), Military (if the chief executive is a military officer) and DefMin (if the defence ministry is a military officer). From the Polity IV Project (2013 data) Polity (combined polity score). From World Bank Country Policy and Institutional Assessment, Corruption Control and Rule of law. From freedom House, Pol_Lib (political rights) and Status (freedom status).

${ }^{18}$ Results for the rest of Alliance variables are presented in the Appendix, Table A.3 and A.4. They are in line with those of NATO.
} 
[insert Table 7 around here]

Therefore, the belonging or having a special partnership with NATO has positive effects on growth with independence of the measure introduced, the subsample analysed, the inclusion of additional controls and institutional measures, different period size and the exclusion of the USA.

\section{Conclusions}

We present a general equilibrium endogenous growth model that allows us to study the defence spending and growth relationship in a country engaged in military cooperation. Common defence policy improves security and welfare. It may also change the level of public funds devoted to defence spending and therefore, affect the level of output. The final effect will depend both on its initial defence spending and on the external effect exerted by the alliance on the economy.

The empirical analysis is carried out for the particular case of NATO during the period 1950-2014. Results confirm that the prospect of more intensive cooperation with the alliance and increased security has a positive effect on economic growth. This fact clearly reinforces the role of alliance membership. Our results are robust to alternative variable definitions, different subsamples, introduction of additional controls and non-stationarity issues. ${ }^{19}$

Future research on public spending should take into account this additional evidence on the relationship between defence spending and economic growth. The findings suggest that the intensive adaptation of countries' defence strategy and procedures to relatively higher standards may improve economic conditions. Current results confirm the relevance of the military institutional environment and security transformation called for by the NATO.

\footnotetext{
${ }^{19}$ We think that the general features of the theoretical model and the main strategy followed in the empirical analysis may be possibly adopted for a study of other military alliances. The Collective Security Treaty Organization, an intergovernmental military alliance that was signed on 15 May 1992 can be an example. It includes collective action and cooperation among countries (article 7). The treaty commits also to further develop and deepen the military and political cooperation in interests of providing and strengthening of the national, regional and international security.
} 


\section{References}

[1] Aghion, Philippe, Bacchetta, Philippe, Ranciere, Romain and Rogoff, Kenneth, 2009. Exchange Rate Volatility and Productivity Growth: The Role of Financial Development, Journal of Monetary Economics 56, 494-513.

[2] Alptekin, Aynur and Paul Levine, 2012. Military Expenditure and Economic Growth: a Meta-analysis, European Journal of Political Economy 28, 636-650.

[3] Aizenman, Joshua and Glick, Reuven, 2006. Military expenditure, Threats and Growth, Journal of International Trade and Economic Development 15, 129-155.

[4] Arellano, Manuel and Bover, Olimpia, 1995. Another Look at the Instrumental Variable Estimation of Error-Components Models, Journal of Econometrics 68, 29-51.

[5] Barro, J. Robert, 1990. Government Spending in a Simple Model of Endogenous Growth, Journal of Political Economy 98, S103-S125.

[6] Barro, J. Robert and Lee, Jong-Wha, 2013. A New Data Set of Educational Attainment in the World, 1950-2010, Journal of Development Economics 104, 184-198.

[7] Beck, Thorsten, 2008. The Econometrics of Finance and Growth. Palgrave Handbook of Econometrics, Vol. 2.

[8] Becker, Jordan, 2017. The Correlates of Transatlantic Burden Sharing: Revising the Agenda for Theoretical and Policy Analysis, Defense and Security Analysis, DOI:10.1080/14751798.2017.1311039

[9] Callado-Muñoz, Francisco J., Hromcová, Jana and Utrero-González, Natalia, 2013. Openness and Technology Diffusion in Payment Systems: The Case of NAFTA, Computational Economics 43, 497-519.

[10] Callado-Muñoz, Francisco J., Hromcová, Jana and Utrero-González, Natalia, 2016. Effects of Institutional Environment and Technology Development on Payment Choice, Technological and Economic Development of Economy, forthcoming, DOI: 10.3846/20294913.2015.1074952

[11] Chalmers, Malcolm, 2001. The Atlantic burden-sharing debate- widening or fragmenting?, International Affairs 77, 569-585.

[12] Clements, Benedict, Bhattacharya, Rina and Nguyen, Toan Q., 2003. External Debt, Public Investment and Growth in Low-Income Countries, IMF WP 03/249.

[13] Compton, Ryan A. and Paterson, Bryan, 2016. Military Spending and Growth: The Role of Institutions, Defence and Peace Economics, 27, 301-322. 
[14] D'Agostino, Giorgio, Dunne, Paul. J. and Pieroni, Luca, 2017. Does Military Spending Matter for Long-Run Growth?, Defence and Peace Economics. DOI: 10.1080/10242694.2017.1324723

[15] Di Liberto, Adriana, Mura, Roberto and Pigliaru, Francesco, 2008. How to Measure the Unobservable: A Panel Technique for the Analysis of TFP Convergence, Oxford Economic Papers 60, 343-368.

[16] Dunne, Paul J., Smith, Ron P. and Willenbockel, Dirk, 2005. Models of Military Expenditure and Growth: A Critical Review, Defence and Peace Economics 16, 449-461.

[17] EU Global Strategy, 2016. https://europa.eu/globalstrategy/en/global-strategy-foreignand-security-policy-european-union

[18] Funk, Steven. C. (Lieutenant Colonel), 1998. The Changing Face of NATO: Familiar or Unrecognizable into the Next Century? USAWC Strategy Research Project. US Army War College.

[19] Gleditsch, Nils Petter, Wallensteen, Peter, Eriksson, Mikael, Sollenberg, Margareta and Strand, Havard, 2002. Armed Conflict 1946-2001: A New Dataset, Journal of Peace Research 39, 615-637.

[20] Kim, Jaechun, 2015. Alliance Adjustment in the Post-Cold War Era: Convergence of Strategic Perceptions and Revitalization of the ROK-US alliance, Pacific Focus 30, 33-58.

[21] Klenow, Peter J. and Rodriguez-Clare, Andrés, 2005. Externalities and Growth. In: Handbook of Economic Growth, 1st ed.; Aghion, Philippe, Durlauf, Steven Eds., Volume 1, Chapter 11, 817-861, Elsevier.

[22] Kugler, Richard L., 1998. Commitment to Purpose: How Alliance Partnership Won the Cold War, Santa Monica, CA. Rand.

[23] Korkmaz, Suna, 2015. The Effect of Military Spending on Economic Growth and Unemployment in Mediterranean Countries, International Journal of Economics and Financial Issues 5, 273-280.

[24] La Porta, Rafael, Lopez-de-Silanes, Florencio Shleifer, Andrei and Vishny, Robert W., 1997. Legal Determinants of External Finance. Journal of Finance 52, 1131-1150.

[25] Macnair, Elizabeth. S., Murdoch, James C. and Pi, Chung-Ron, 1995. Growth and Defence: Pooled Estimates for the NATO Alliance, 1951-1988, Southern Economic Journal 61, 846860.

[26] Mattelaer, Alexander, 2016. Revisiting the Principles of NATO Burden-Sharing, Parameters $46,25-33$. 
[27] Mattox, Gale A., 1998. NATO Enlargement: A Step in The Process of Alliance Reform in The Post-Cold War. University of California, Berkeley. Center for German and European Studies, Working Paper 5.71.

[28] Musayev, Vusal, 2013. Military Spending and Growth: An Empirical Exploration of Contingent Relationships, MPRA WP 59783.

[29] Musayev, Vusal, 2016. Externalities in Military Spending and Growth: The Role of Natural Resources as a Channel through Conflict, Defence and Peace Economics 27, 378-391.

[30] NATO. 2010. Strategic Concept. NATO web page, http://www.nato.int

[31] NATO. 2014. Partnerships. NATO web page, http://www.nato.int

[32] NATO. 2015a. Enlargement. NATO web page, http://www.nato.int

[33] NATO. 2015b. Standarization. NATO web page, http://www.nato.int

[34] NATO. 2017. Funding Nato. NATO web page, http://www.nato.int/cps/en/natohq/topics_67655.htm

[35] Olson, Mancur, 1965. The Logic of Collective Action. Cambridge, MA: Harvard U. Press.

[36] Olson, Mancur and Zeckhauser, Richard, 1966. An Economic Theory of Alliances, Review of Economics and Statistics 48, 266-79.

[37] Pieroni, Luca, 2009. Military Expenditure and Economic Growth, Defence and Peace Economics 20, 327-339.

[38] Presbitero, Andrea F. 2006. The Debt-Growth Nexus: A Dynamic Panel Data Estimation, Rivista Italiana degli Economisti 3, 417-462.

[39] Roodman, David, 2009. How to Do xtabond2: An Introduction to "Difference" and "System" GMM in Stata, The Stata Journal 9, 86-136.

[40] Ruíz, Rosa, 2014. La OTAN se reafirma, Revista Española de Defensa, Septiembre, 7-11.

[41] Sandler, Todd and Murdoch, James C., 2000. On Sharing NATO Defence Burdens in the 1990s and Beyond, Fiscal Studies 21, 297-327.

[42] Sandler, Todd and Hartley, Keith, 2001. Economics of Alliances: The Lessons for Collective Action, Journal of Economic Literature 39, 869-896.

[43] Shieh, Jhy-yuan, Lai, Ching-chong and Chang, Wen-ya, 2002. The Impact of Military Burden on Long-Run Growth and Welfare, Journal of Development Economics 68, 443454.

[44] Szayna, Thomas S., 2001. NATO Enlargement 2000-2015: Determinants and Implications for Defense Planning and Shaping. Project AIR FORCE RAND. 
[45] Töngür, Ünal and Elveren Adem Y., 2012. Military Expenditures, Inequality, and Welfare and Political Regimes: A Dynamic Panel Data Analysis, ERC Working Papers in Economics 12/10.

[46] Wallander, Celeste. A., 2000. Institutional Assets and Adaptability: NATO after the Cold War, International Organization 54, 705-735.

[47] Walt, Stephen M., 1997. Why Alliances Endure or Collapse, Survival 39, 156-179.

[48] Webber, Mark, Sperling, James and Smith, Martin A., 2012. NATO's Post-Cold War Trajectory. Decline and Regeneration. Palgrave McMillan UK.

[49] Yakovlev, Pavel. 2007. Arms Trade, Military Spending and Economic Growth, Defence and Peace Economics 18, 317-338. 
Figure 1. Evolution of the relationship between NATO and its partners/membres.

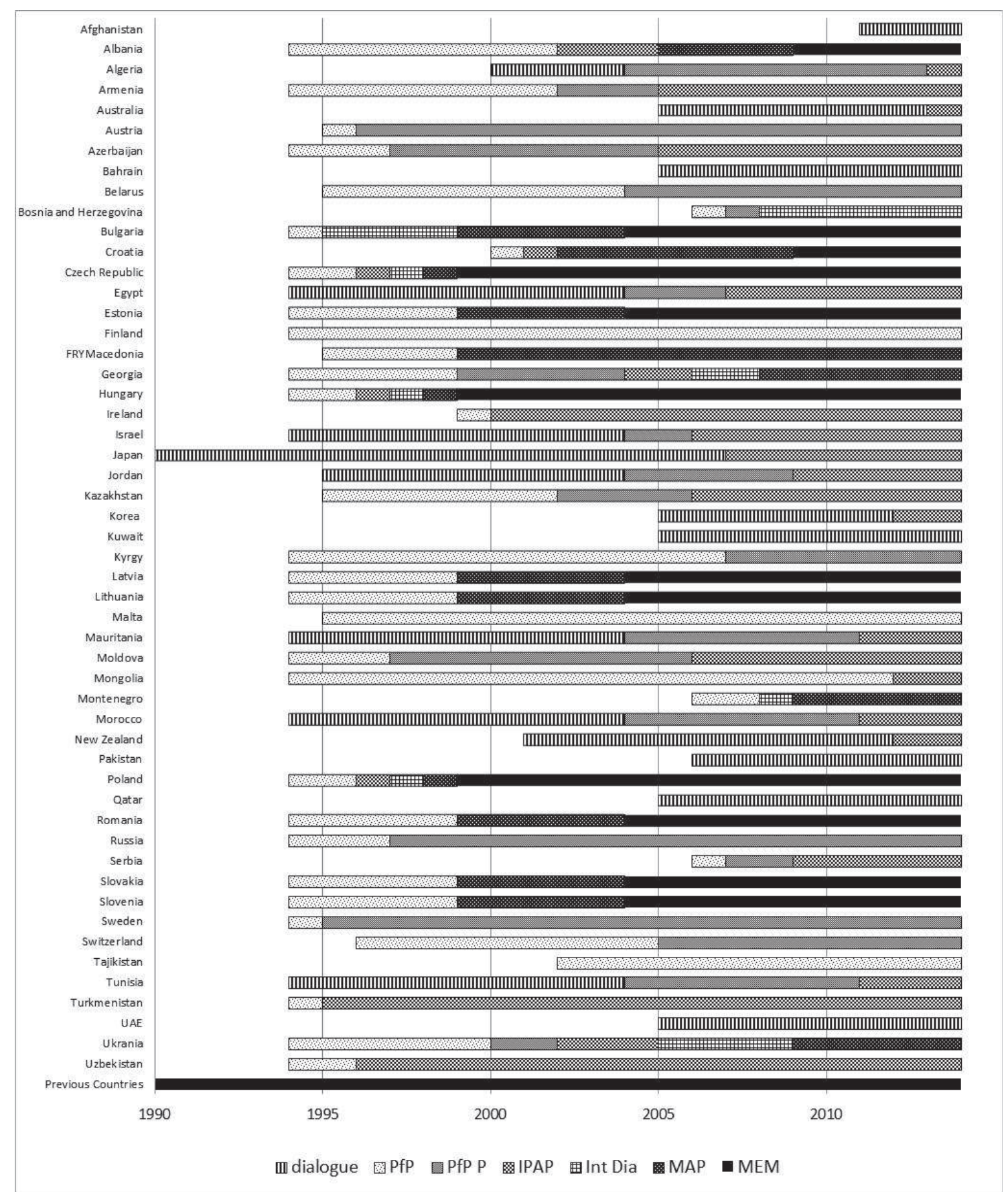

Note: Dialogue accounts for political dialogue; PfP is Partnership for Peace program; PfP P accounts for PARP (Partnership for peace program planning and Review Process); IPAP is Individual Partnership Action Plan, Int Dia means intensive dialogue previous to Membership Action Plan (MAP); MEM means MEMbership.

Previuos Members: Belgium, Canada, Denmark, United States, France, Iceland, Italy, Luxembourg, Norway, Netherlands, Portugal, United Kingdom, Greece, Turkey, Germany, Spain. 
Figure 2A. Evolution of defence spending to GDP in founding countries, new members and partners.

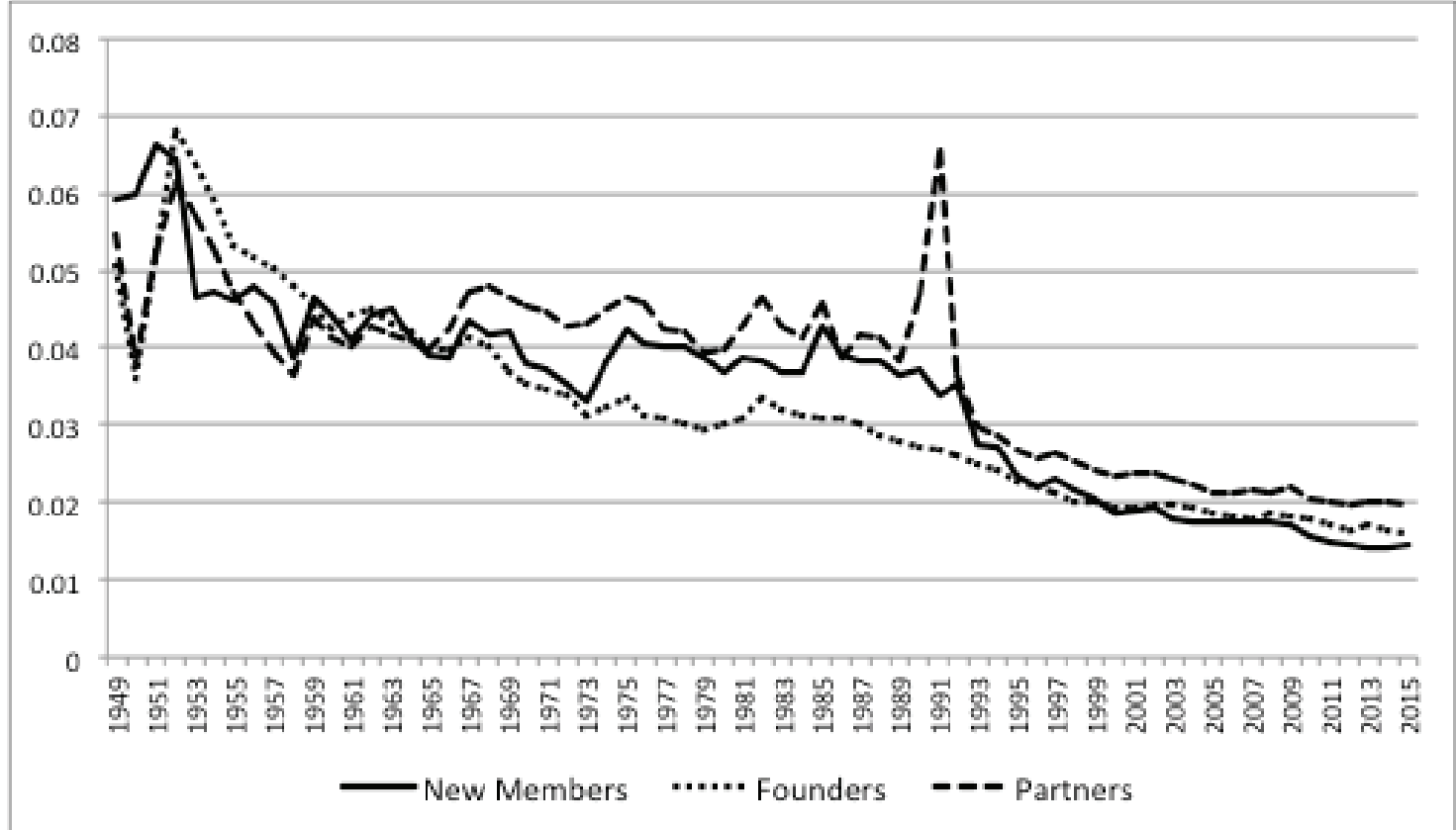

Founders: Belgium, Canada, Denmark, France, Iceland, Italy, Luxembourg, Netherlands, Norway, Portugal, United Kingdom , United States

New members: Bulgaria, Croatia, Czech Republic, Estonia, Finland, Germany, Greece, Hungary, Latvia, Lithuania, Poland, Romania, Slovakia, Slovenia, Spain, Turkey

Partners: Afghanistan, Algeria, Armenia, Australia, Austria, Azerbaijan, Bahrain, Belarus, Bosnia and Herzegovina, Egypt, FRYMacedonia, Georgia, Ireland, Israel, Japan, Jordan, Kazakhstan, Korea, Kyrgyztan, Malta, Mauritania, Moldova, Mongolia, Montenegro, Morocco, New Zealand, Qatar, Pakistan, Russia, Serbia, Sweden, Switzerland, Tajikistan, Tunisia, Turkmenistan, UAE, Ukrania, Uzbekistan.

Figure 2B. Evolution of defence spending to GDP for countries entering NATO, by entry date.

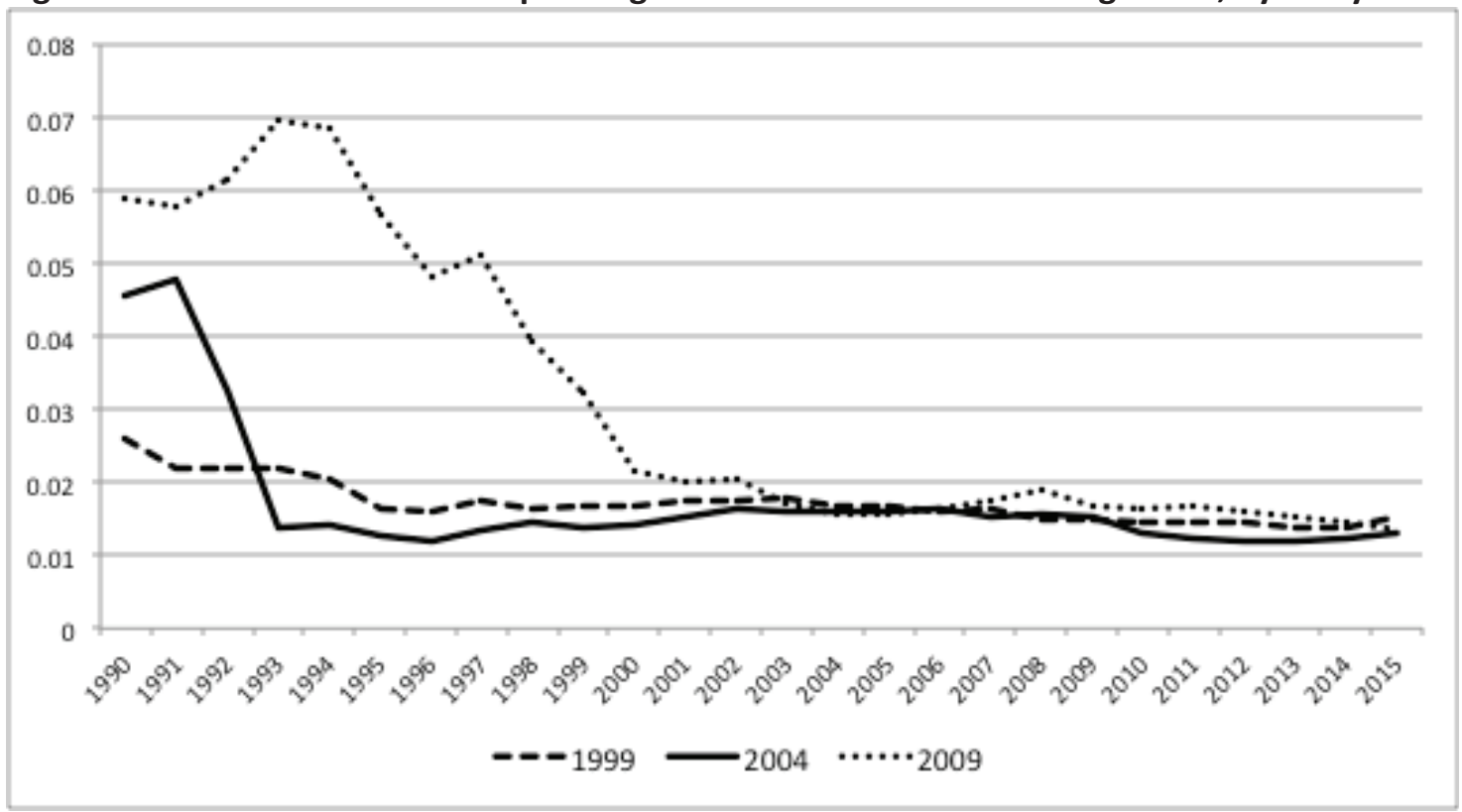

1999: Czech Republic, Hungary, Poland. 2004: Bulgaria, Estonia, Latvia, Lithuania, Romania, Slovakia, Slovenia. 2009: Albania, Croatia. 
Table 1. Summary Statistics.

\begin{tabular}{lccccc}
\hline \hline Variable & Obs & Mean & Std. Dev. & Min & Max \\
\hline \hline GDP per capita growth & 969 & 0.0276 & 0.0585 & -0.4138 & 0.5356 \\
GDP per capita (log) & 969 & 9.3347 & 1.0154 & 5.5468 & 11.8918 \\
$\begin{array}{l}\text { Military Expenditure } \\
\text { over GDP }\end{array}$ & 967 & 0.0311 & 0.0321 & 0.0005 & 0.4384 \\
$\begin{array}{l}\text { Military Expenditure } \\
\text { per capita (log) }\end{array}$ & 967 & 55266 & 1.3659 & 0.9060 & 9.4770 \\
$\begin{array}{l}\text { Public Investment over } \\
\text { GDP }\end{array}$ & 969 & 0.2266 & 0.0769 & 0.0284 & 0.4988 \\
$\begin{array}{l}\text { Public Consumption over } \\
\text { GDP }\end{array}$ & 969 & 0.2021 & 0.0926 & 0.0284 & 0.6381 \\
NATO & 969 & 0.4638 & 0.4527 & 0.0000 & 1.0000 \\
NATO_benefit & 969 & 0.7229 & 1.3845 & 0.0000 & 18.2811 \\
NATO_partner benefit & 969 & 1.6489 & 3.6347 & 0.0000 & 57.8162 \\
$\begin{array}{l}\text { Population Growth } \\
\text { Schooling (log) }\end{array}$ & 969 & 0.4904 & 1.1364 & -1.2054 & 7.5875 \\
\hline
\end{tabular}


Table 2: Panel A. Military Spending, NATO and growth: military expenditure over GDP.

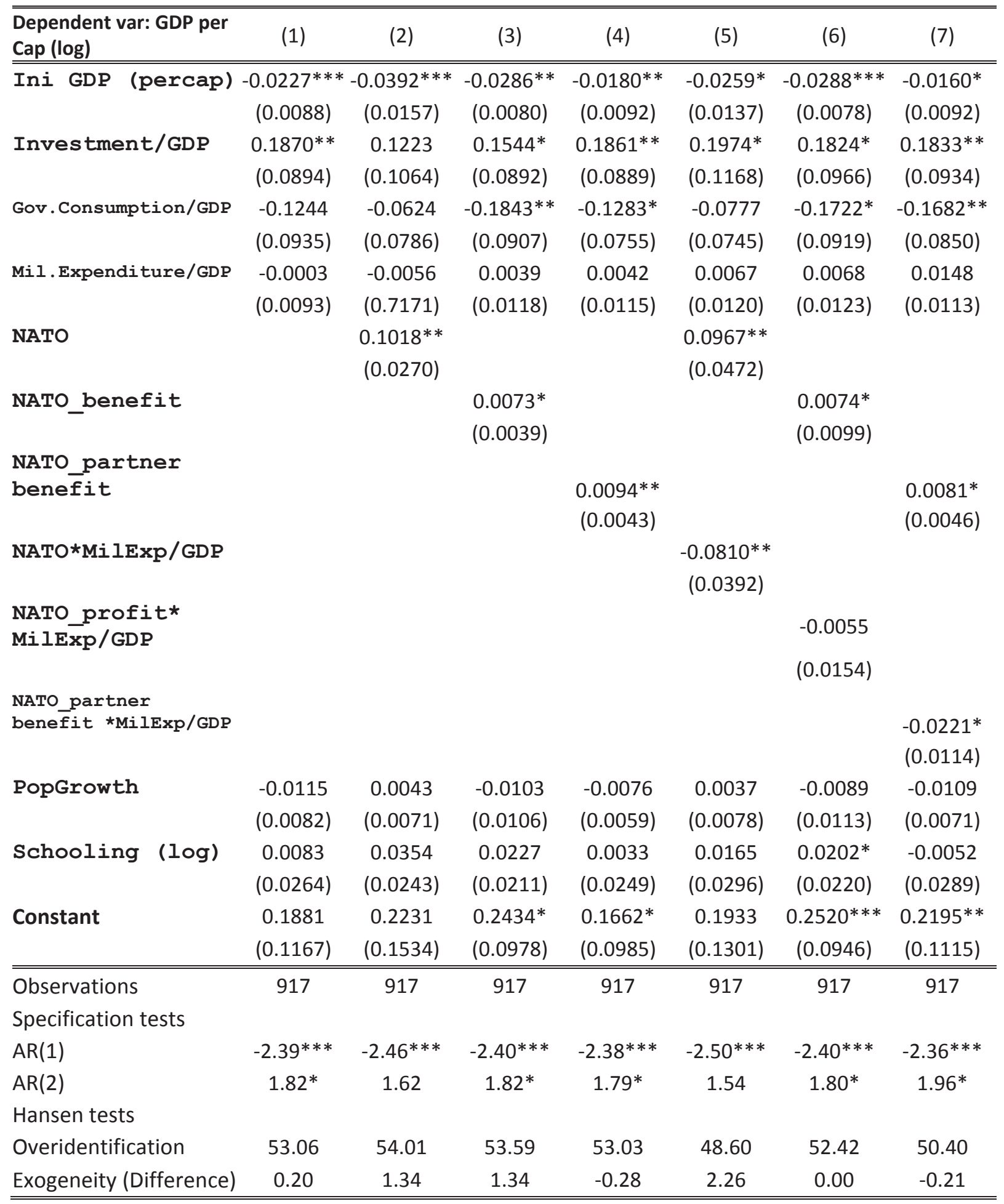

Dependent variable: logged per capita GDP growth. All specifications include time effects (NATO key events) as defined by NATO. Estimation: system GMM with Windmeijer (2005) small sample robust correction. To avoid over-fitting the instrument matrix is collapsed. Robust standard errors in parentheses. Significance levels: $* * *$ at $1 \%, * *$ at $5 \%$ and $*$ at $10 \%$. 
Table 2: Panel B. Military Spending, NATO and growth: per capita military expenditure.

\begin{tabular}{|c|c|c|c|c|c|c|c|}
\hline $\begin{array}{l}\text { Dependent var: GDP per } \\
\text { Cap (log) }\end{array}$ & (1) & (2) & (3) & (4) & (5) & (6) & (7) \\
\hline Ini GDP (percap) & $\begin{array}{l}-0.0229 \\
(0.0201)\end{array}$ & $\begin{array}{l}-0.0440 * \\
(0.0245)\end{array}$ & $\begin{array}{c}-0.0326^{* *} \\
(0.0153)\end{array}$ & $\begin{array}{l}-0.0225 \\
(0.0168)\end{array}$ & $\begin{array}{l}-0.0447^{*} \\
(0.0171)\end{array}$ & $\begin{array}{c}-0.0347^{* *} \\
(0.0163)\end{array}$ & $\begin{array}{l}-0.0299 * \\
(0.0168)\end{array}$ \\
\hline Investment/GDP & $\begin{array}{r}0.1896 * * \\
(0.0797)\end{array}$ & $\begin{array}{c}0.1222 \\
(0.1165)\end{array}$ & $\begin{array}{l}0.1674 * \\
(0.0977)\end{array}$ & $\begin{array}{r}0.1825^{* *} \\
(0.0861)\end{array}$ & $\begin{array}{c}0.1772 * \\
(0.09380)\end{array}$ & $\begin{array}{l}0.1778 * * \\
(0.0824)\end{array}$ & $\begin{array}{l}0.2156^{* *} \\
(0.0845)\end{array}$ \\
\hline Gov.Consumption/GDP & $\begin{array}{l}-0.0937 \\
(0.0846)\end{array}$ & $\begin{array}{l}-0.0237 \\
(0.0716)\end{array}$ & $\begin{array}{c}-0.1304 * * \\
(0.0724)\end{array}$ & $\begin{array}{l}-0.0876 \\
(0.0642)\end{array}$ & $\begin{array}{l}-0.0875 \\
(0.0858)\end{array}$ & $\begin{array}{l}-0.1293 \\
(0.0802)\end{array}$ & $\begin{array}{l}-0.1098 * \\
(0.0667)\end{array}$ \\
\hline $\begin{array}{l}\text { Per Cap Mil. } \\
\text { Expenditure }\end{array}$ & $\begin{array}{c}0.0009 \\
(0.0118)\end{array}$ & $\begin{array}{c}0.0005 \\
(0.0119)\end{array}$ & $\begin{array}{c}0.0046 \\
(0.0100)\end{array}$ & $\begin{array}{c}0.0059 \\
(0.0120)\end{array}$ & $\begin{array}{l}0.0153 * \\
(0.0085)\end{array}$ & $\begin{array}{c}0.0074 \\
(0.0106)\end{array}$ & $\begin{array}{c}0.0135 \\
(0.0127)\end{array}$ \\
\hline NATO & & $\begin{array}{c}0.1118 * * \\
(0.0443)\end{array}$ & & & $\begin{array}{c}0.0601 * * \\
(0.0305)\end{array}$ & & \\
\hline NATO_benefit & & & $\begin{array}{l}0.0066^{*} \\
(0.0039)\end{array}$ & & & $\begin{array}{c}0.0045 \\
(0.0037)\end{array}$ & \\
\hline $\begin{array}{l}\text { NATO_partner } \\
\text { benefit }\end{array}$ & & & & $\begin{array}{l}0.0113^{* *} \\
(0.0045)\end{array}$ & & & $\begin{array}{r}0.0087^{* *} \\
(0.0039)\end{array}$ \\
\hline $\begin{array}{l}\text { NATO*Per Cap } \\
\text { MilExp }\end{array}$ & & & & & $\begin{array}{c}-0.0464 * * \\
(0.0197)\end{array}$ & & \\
\hline $\begin{array}{l}\text { NATO_benefit* } \\
\text { Per Cap MilExp }\end{array}$ & & & & & & $\begin{array}{l}-0.0081 \\
(0.0122)\end{array}$ & \\
\hline $\begin{array}{l}\text { NATO_partner } \\
\text { benefit *Per Cap } \\
\text { MilExp }\end{array}$ & & & & & & & $\begin{array}{r}-0.0166 * * \\
(0.0078)\end{array}$ \\
\hline PopGrowth & $\begin{array}{l}-0.0095 \\
(0.0073)\end{array}$ & $\begin{array}{c}0.0066 \\
(0.0063)\end{array}$ & $\begin{array}{l}-0.0069 \\
(0.0086)\end{array}$ & $\begin{array}{l}-0.0060 \\
(0.0067)\end{array}$ & $\begin{array}{c}0.0037 \\
(0.0072)\end{array}$ & $\begin{array}{l}-0.0050 \\
(0.0091)\end{array}$ & $\begin{array}{l}-0.0072 \\
(0.0078)\end{array}$ \\
\hline Schooling (log) & $\begin{array}{c}0.0129 \\
(0.0234)\end{array}$ & $\begin{array}{c}0.435^{*} \\
(0.0248)\end{array}$ & $\begin{array}{c}0.0205 \\
(0.0184)\end{array}$ & $\begin{array}{c}0.0048 \\
(0.0246)\end{array}$ & $\begin{array}{c}0.0193 \\
(0.0252)\end{array}$ & $\begin{array}{c}0.0198 \\
(0.0162)\end{array}$ & $\begin{array}{l}-0.0040 \\
(0.0263)\end{array}$ \\
\hline Constant & $\begin{array}{c}0.1703 \\
(0.1363)\end{array}$ & $\begin{array}{c}0.2571 \\
(0.1633) \\
\end{array}$ & $\begin{array}{c}0.2295^{* *} \\
(0.0972) \\
\end{array}$ & $\begin{array}{c}0.1557 \\
(0.1045) \\
\end{array}$ & $\begin{array}{l}0.2588^{*} \\
(0.1012)\end{array}$ & $\begin{array}{c}0.2337^{* *} \\
(0.1041)\end{array}$ & $\begin{array}{c}0.1742 \\
(0.1126)\end{array}$ \\
\hline $\begin{array}{l}\text { Observations } \\
\text { Specification tests }\end{array}$ & 917 & 917 & 917 & 917 & 917 & 917 & 917 \\
\hline $\operatorname{AR}(1)$ & $-2.38 * * *$ & $-2.43 * * *$ & $-2.38 * * *$ & $-2.36 * * *$ & $-2.38 * * *$ & $-2.37 * * *$ & $-2.35^{* * *}$ \\
\hline$A R(2)$ & $1.83^{*}$ & 1.65 & 1.79* & $1.77^{*}$ & 1.58 & $1.74 *$ & $1.70^{*}$ \\
\hline Hansen tests & & & & & & & \\
\hline Overidentification & 53.08 & 53.8 & 53.14 & 55.29 & 49.49 & 51.65 & 51.76 \\
\hline Exogeneity (Difference) & 0.31 & 1.77 & -0.65 & 4.56 & 3.31 & -1.02 & 2.91 \\
\hline
\end{tabular}

Dependent variable: logged per capita GDP growth. All specifications include time effects (NATO key events) as defined by NATO. Estimation: system GMM with Windmeijer (2005) small sample robust correction. To avoid over-fitting the instrument matrix is collapsed. Robust standard errors in parentheses. Significance levels: ${ }^{* * *}$ at $1 \%, * *$ at $5 \%$ and ${ }^{*}$ at $10 \%$. 


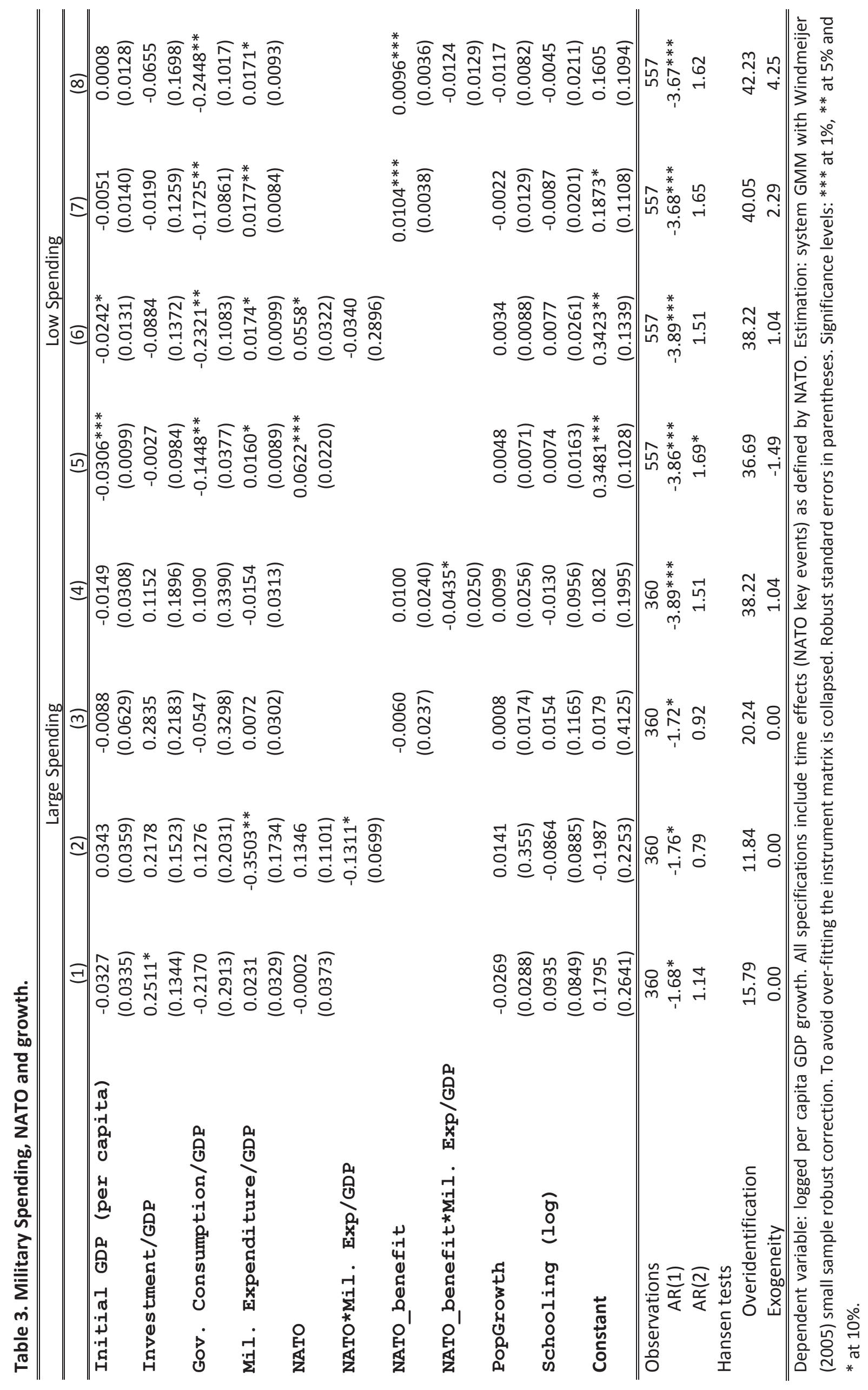




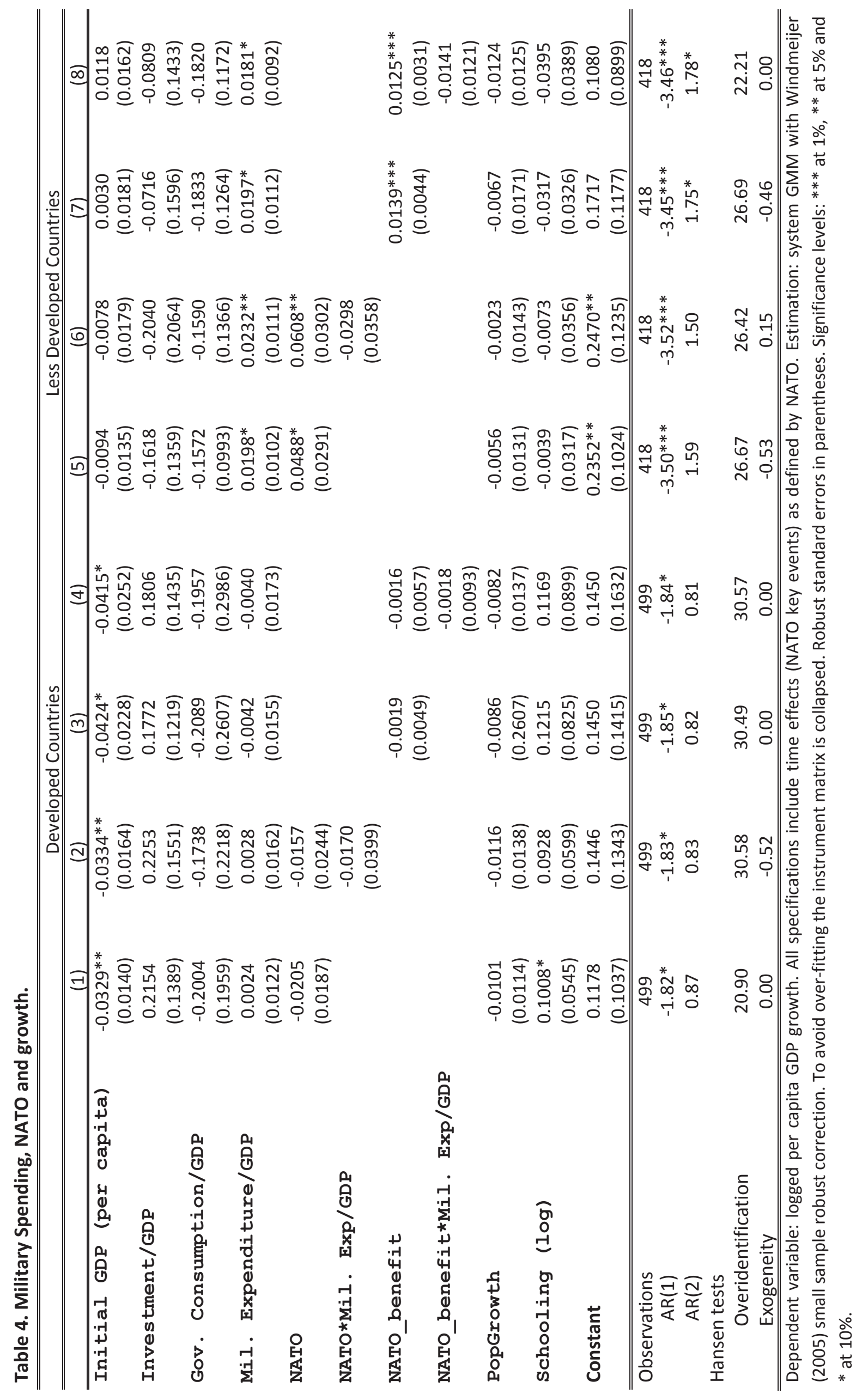




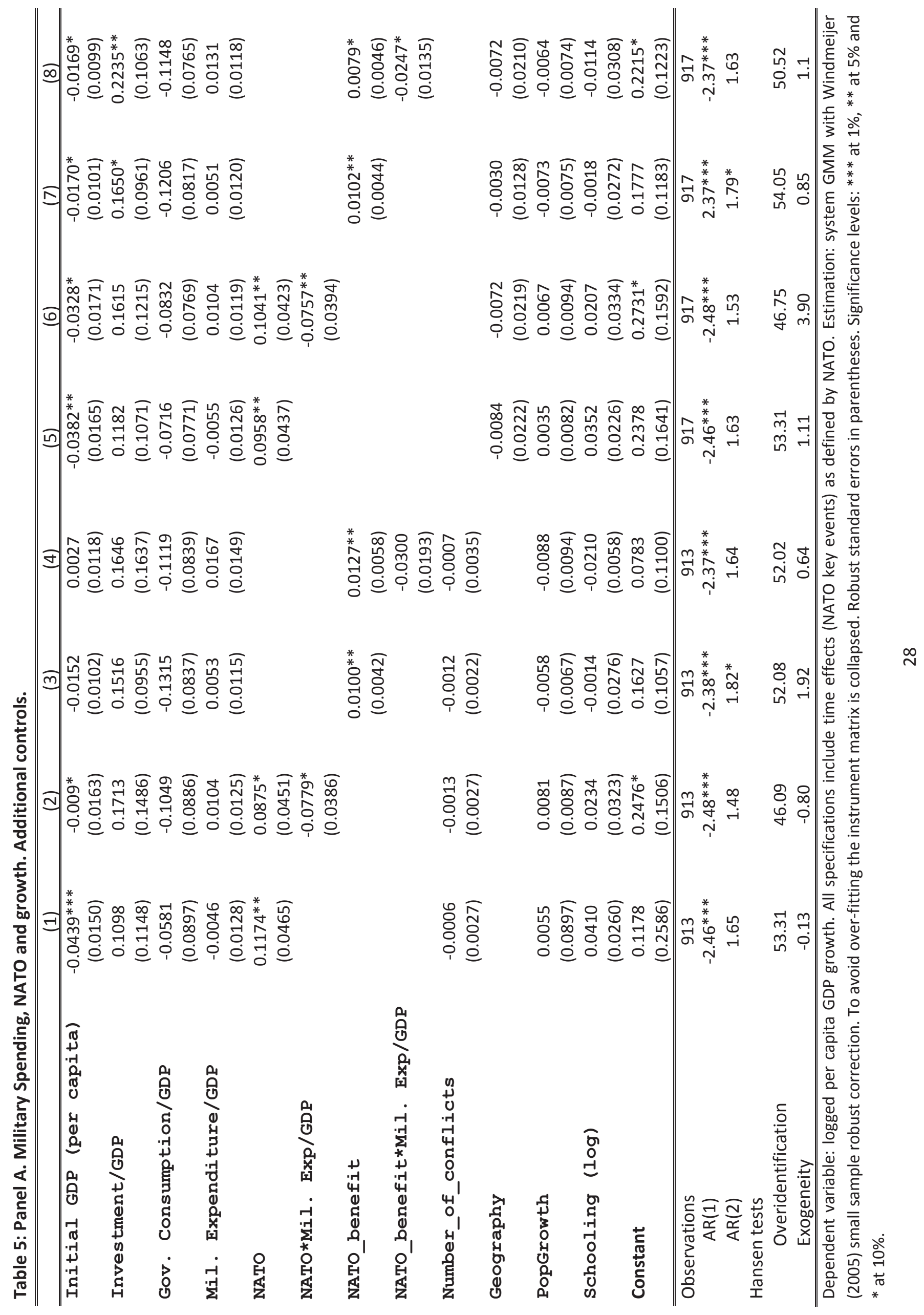




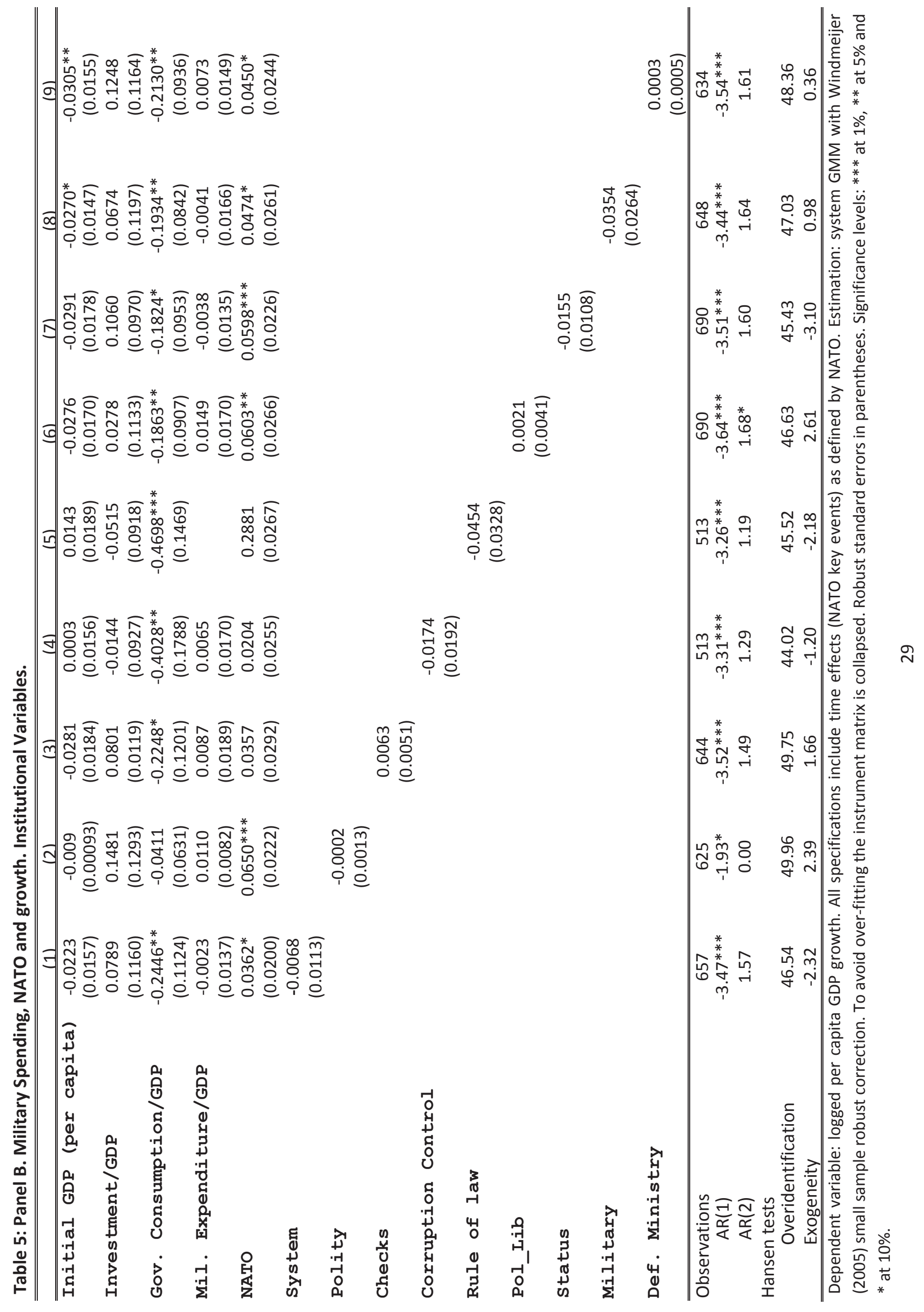


Table 6. Military Spending, NATO and growth. Sample without USA.

\begin{tabular}{|c|c|c|c|c|c|c|}
\hline Dependent var: GDP per Cap (log) & (1) & (2) & (3) & (4) & (5) & (6) \\
\hline Initial GDP (percap) & $\begin{array}{c}-0.0402 * * * \\
(0.0145)\end{array}$ & $\begin{array}{c}-0.0323^{* *} \\
(0.0155)\end{array}$ & $\begin{array}{l}-0.0228 \\
(0.0107)\end{array}$ & $\begin{array}{l}-0.0158 \\
(0.0100)\end{array}$ & $\begin{array}{l}-0.0121 \\
(0.0124)\end{array}$ & $\begin{array}{c}-0.0180^{* *} \\
(0.0089)\end{array}$ \\
\hline Investment/GDP & $\begin{array}{c}0.1163 \\
(0.1206)\end{array}$ & $\begin{array}{c}0.1749 \\
(0.1189)\end{array}$ & $\begin{array}{c}0.1346 \\
(0.0966)\end{array}$ & $\begin{array}{c}0.1570 \\
(0.0978)\end{array}$ & $\begin{array}{c}0.2245 \\
(0.1737)\end{array}$ & $\begin{array}{c}0.2515^{* *} \\
(0.1105)\end{array}$ \\
\hline Gov. Consumption/GDP & $\begin{array}{l}-0.0710 \\
(0.0897)\end{array}$ & $\begin{array}{l}-0.0927 \\
(0.0664)\end{array}$ & $\begin{array}{l}-0.1073 \\
(0.0680)\end{array}$ & $\begin{array}{l}-0.1393 * \\
(0.0810)\end{array}$ & $\begin{array}{l}-0.0564 \\
(0.1030)\end{array}$ & $\begin{array}{l}-0.1130 \\
(0.0690)\end{array}$ \\
\hline Mil. Expenditure/GDP & $\begin{array}{l}-0.0068 \\
(0.0130)\end{array}$ & $\begin{array}{c}0.0097 \\
(0.0146)\end{array}$ & $\begin{array}{c}0.0027 \\
(0.0124)\end{array}$ & $\begin{array}{c}0.0049 \\
(0.0124)\end{array}$ & $\begin{array}{c}0.0131 \\
(0.0163)\end{array}$ & $\begin{array}{c}0.0091 \\
(0.0116)\end{array}$ \\
\hline NATO & $\begin{array}{l}0.1036^{* *} \\
(0.0428)\end{array}$ & $\begin{array}{l}0.1064^{* *} \\
(0.0438)\end{array}$ & & & & \\
\hline NATO_benefit & & & $\begin{array}{c}0.0157 \\
(0.0152)\end{array}$ & & $\begin{array}{c}0.0086 \\
(0.0120)\end{array}$ & \\
\hline NATO_partner benefit & & & & $\begin{array}{l}0.0106 * * \\
(0.0042)\end{array}$ & & $\begin{array}{l}0.0070^{*} \\
(0.0043)\end{array}$ \\
\hline $\begin{array}{l}\text { NATO*Mil. } \\
\text { Expenditure/GDP }\end{array}$ & & $\begin{array}{c}-0.0724^{* *} \\
(0.0316)\end{array}$ & & & & \\
\hline $\begin{array}{l}\text { NATO_benefit*Mil. } \\
\operatorname{Exp/GDP}\end{array}$ & & & & & $\begin{array}{l}-0.0398 * \\
(0.0225)\end{array}$ & \\
\hline $\begin{array}{l}\text { NATO_partner benefit } \\
\text { *Mil.Exp/GDP }^{\text {Mil }}\end{array}$ & & & & & & $\begin{array}{l}-0.0052 * \\
(0.0129)\end{array}$ \\
\hline PopGrowth & $\begin{array}{c}0.0070 \\
(0.0135)\end{array}$ & $\begin{array}{c}0.0064 \\
(0.0117)\end{array}$ & $\begin{array}{c}0.0015 \\
(0.0097)\end{array}$ & $\begin{array}{l}-0.0075 \\
(0.0068)\end{array}$ & $\begin{array}{c}0.0001 \\
(0.0114)\end{array}$ & $\begin{array}{l}-0.0089 \\
(0.0060)\end{array}$ \\
\hline Schooling (log) & $\begin{array}{c}0.0372 \\
(0.0234)\end{array}$ & $\begin{array}{c}0.0206 \\
(0.0302)\end{array}$ & $\begin{array}{c}0.0182 \\
(0.0283)\end{array}$ & $\begin{array}{c}0.0006 \\
(0.0256)\end{array}$ & $\begin{array}{l}-0.0218 \\
(0.0341)\end{array}$ & $\begin{array}{l}-0.0080 \\
(0.0274)\end{array}$ \\
\hline Constant & $\begin{array}{c}0.2350 \\
(0.1468)\end{array}$ & $\begin{array}{l}0.2607 * \\
(0.1583)\end{array}$ & $\begin{array}{c}0.1807 \\
(0.1161)\end{array}$ & $\begin{array}{c}0.1684 \\
(0.1054)\end{array}$ & $\begin{array}{c}0.1821 \\
(0.1372)\end{array}$ & $\begin{array}{l}0.2038 * \\
(0.1007)\end{array}$ \\
\hline Observations & 895 & 895 & 895 & 895 & 895 & 895 \\
\hline Specification tests & & & & & & \\
\hline $\operatorname{AR}(1)$ & $-2.45 * * *$ & $-2.47^{* * *}$ & $-2.37 * * *$ & $-2.36 * * *$ & $-2.43 * * *$ & $-2.39 * * *$ \\
\hline$A R(2)$ & 1.61 & 1.53 & $1.73 *$ & $1.74 *$ & 1.65 & 1.66 \\
\hline Hansen tests & & & & & & \\
\hline Overidentification & 50.55 & 43.74 & 50.78 & 53.04 & 49.06 & 46.62 \\
\hline Exogeneity (Difference) & -1.14 & -1.83 & -0.97 & 0.6 & 0.24 & -2.82 \\
\hline
\end{tabular}

Dependent variable: logged per capita GDP growth. All specifications include time effects (NATO key events) as defined by NATO. Estimation: system GMM with Windmeijer (2005) small sample robust correction. To avoid over-fitting the instrument matrix is collapsed. Robust standard errors in parentheses. Significance levels: ${ }^{* * *}$ at $1 \%, * *$ at $5 \%$ and $*$ at $10 \%$. 
Table 7. Military Spending, 5 year period.

\begin{tabular}{|c|c|c|c|c|c|c|}
\hline $\begin{array}{l}\text { Dependent var: GDP per } \\
\text { Cap (log) }\end{array}$ & (1) & $(2)$ & (3) & (4) & (5) & (6) \\
\hline \multirow[t]{2}{*}{$\begin{array}{l}\text { Initial GDP (per } \\
\text { capita) }\end{array}$} & $-0.0495 * * *$ & $-0.0422 * * *$ & -0.0153 & $-0.0548 * * *$ & $-0.0396 * * *$ & -0.0181 \\
\hline & $(0.0129)$ & $(0.0127)$ & $(0.0115)$ & $(0.0111)$ & $(0.0091)$ & $(0.0144)$ \\
\hline \multirow[t]{2}{*}{ Investment/GDP } & $0.3402^{* * *}$ & $0.3494^{* * *}$ & $0.4027^{* *}$ & $0.3406^{* * *}$ & $0.2844^{* * *}$ & $0.4497^{* * *}$ \\
\hline & $(0.1094)$ & (0.1090) & $(0.1553)$ & $(0.1171)$ & $(0.1036)$ & $(0.1457)$ \\
\hline \multirow[t]{2}{*}{$\begin{array}{l}\text { Gov. } \\
\text { Consumption/GDP }\end{array}$} & -0.0626 & -0.1242 & -0.0943 & -0.1031 & -0.1818 & -0.1031 \\
\hline & $(0.1037)$ & $(0.0886)$ & (0.0799) & $(0.1067)$ & $(0.1189)$ & $(0.0935)$ \\
\hline \multirow[t]{2}{*}{ Mil.Expenditure/GDP } & 0.5828 & 0.5895 & 0.3939 & 0.6160 & 0.6216 & 0.3921 \\
\hline & $(0.4402)$ & $(0.4156)$ & $(0.3091)$ & $(0.5357)$ & $(0.4907)$ & (0.3009) \\
\hline \multirow[t]{2}{*}{ NATO } & $0.0968 * * *$ & & & $0.1226 * * *$ & & \\
\hline & $(0.0287)$ & & & $(0.0398)$ & & \\
\hline \multirow[t]{2}{*}{ NATO_benefit } & & $0.0185^{* *}$ & & & $0.0269 *$ & \\
\hline & & $(0.0086)$ & & & $(0.0146)$ & \\
\hline \multirow{2}{*}{$\begin{array}{l}\text { NATO_partner } \\
\text { benefit }\end{array}$} & & & & & & \\
\hline & & & $\begin{array}{l}0.0153^{* *} \\
(0.0077)\end{array}$ & & & $\begin{array}{l}0.0159 * \\
(0.0096)\end{array}$ \\
\hline \multirow[t]{2}{*}{$\begin{array}{l}\text { NATO*Mil. } \\
\text { Expenditure/GDP }\end{array}$} & & & & $-0.08507^{*}$ & & \\
\hline & & & & $(0.0303)$ & & \\
\hline \multirow[t]{2}{*}{$\begin{array}{l}\text { NATO_benefit* } \\
\text { Mil.Exp/GDP }\end{array}$} & & & & & -0.0149 & \\
\hline & & & & & $(0.0461)$ & \\
\hline \multirow{2}{*}{$\begin{array}{l}\text { NATO_partner } \\
\text { benefit*Mil.Exp/GDP }\end{array}$} & & & & & & \\
\hline & & & & & & $\begin{array}{c}-0.0068 \\
(0.00093)\end{array}$ \\
\hline \multirow[t]{2}{*}{ PopGrowth } & 1.1285 & 0.7802 & -0.0449 & 1.1288 & 0.5634 & 0.0166 \\
\hline & (1.9453) & $(1.7751)$ & $(1.3236)$ & $(2.0980)$ & $(2 . .1781)$ & $(1.2751)$ \\
\hline \multirow[t]{2}{*}{ Schooling (log) } & 0.0644 & 0.0606 & -0.0034 & 0.0729 & 0.0630 & -0.0071 \\
\hline & $(0.0652)$ & $(0.0622)$ & (0.0439) & $(0.0707)$ & $(0.0886)$ & $(0.0472)$ \\
\hline \multirow[t]{2}{*}{ Constant } & $0.1958^{*}$ & $0.1796^{*}$ & 0.0652 & $0.2413^{*}$ & 0.1692 & 0.0906 \\
\hline & $(0.1085)$ & $(0.0975)$ & $(0.1552)$ & $(0.1458)$ & $(0.2110)$ & $(0.1764)$ \\
\hline Observations & 526 & 526 & 526 & 526 & 526 & 526 \\
\hline \multicolumn{7}{|l|}{ Specification tests } \\
\hline $\operatorname{AR}(1)$ & $-2.08 * * *$ & $-2.07 * * *$ & $-2.21 * * *$ & $-2.50 * * *$ & -1.34 & $-1.91 *$ \\
\hline $\operatorname{AR}(2)$ & -0.61 & -0.48 & -0.84 & 1.54 & -0.79 & -0.85 \\
\hline \multicolumn{7}{|l|}{ Hansen tests } \\
\hline Overidentification & 52.5 & 49.99 & 47.69 & 48.60 & 46.84 & 47.76 \\
\hline Exogeneity (Difference) & 1.99 & 1.94 & -0.44 & 2.26 & -1.43 & -0.65 \\
\hline
\end{tabular}


Appendix:

Table A.1. Panel unit root test for key variables.

\begin{tabular}{|l|l|l|l|}
\hline Variables & IPS & ADF & PP \\
\hline $\begin{array}{l}\text { GDP per capita } \\
\text { growth rate }\end{array}$ & $-12.6432^{* * *}$ & $338.0801^{* * *}$ & $1076.0973^{* * *}$ \\
\hline GDP per capita (log) & $-4.8144^{* * *}$ & $218.5333^{* * *}$ & $245.8729 * * *$ \\
\hline Defence spending/GDP & $-4.2817^{* * *}$ & $324.9972^{* * *}$ & $270.5424 * * *$ \\
\hline NATO & -1.0943 & $161.8372^{*}$ & 150.6842 \\
\hline NATO_benefit & $-1.9930^{* *}$ & $325.1384 * * *$ & 101.0752 \\
\hline NATO_partner benefit & $-2.7721^{* * *}$ & $249.7275^{* * *}$ & $222.6050^{* * *}$ \\
\hline
\end{tabular}

Note: IPS is the Im, Pesaran and Shin test, ADF is the Augmented Dickey-Fuller test and PP is the Phillips-Perron test. Significance levels: $* * *$ at $1 \%, * *$ at $5 \%$ and $*$ at $10 \%$. 
Table A.2: Countries' average defence spending to GDP by quartile.

\begin{tabular}{|l|l|l|l|}
\hline \multicolumn{1}{|c|}{ Q1 } & \multicolumn{1}{|c|}{ Q3 } & \multicolumn{1}{c|}{ Q4 } \\
\hline Algeria & Afghanistan & Australia & Egypt, \\
Belarus & Albania & Bahrain & France \\
Bosnia-Herzegovina & Armenia & Belgium & Greece \\
Estonia & Austria & Bulgaria & Israel \\
Georgia & Azerbaijan & Canada & Jordan \\
Iceland & Czech Rep. & Croatia & Kuwait \\
Kazakhstan & Finland & Denmark & Netherlands \\
Kyrgyztan & Ireland & Germany & Norway \\
Latvia & Japan & Hungary & Portugal \\
Lithuania & Luxemburg & Italy & Qatar \\
Macedonia & Mauritania & New Zealand & UK \\
Malta & Mongolia & Poland & USA \\
Moldova & Morocco & Romania & \\
Montenegro & Pakistan & Russia & \\
Korea & Serbia & Spain & \\
Tajikistan & Slovak Rep. & Sweden & \\
Tunisia & Slovenia & Switzerland & \\
Ukraine & & Turkey & \\
& & UAE & \\
\hline
\end{tabular}




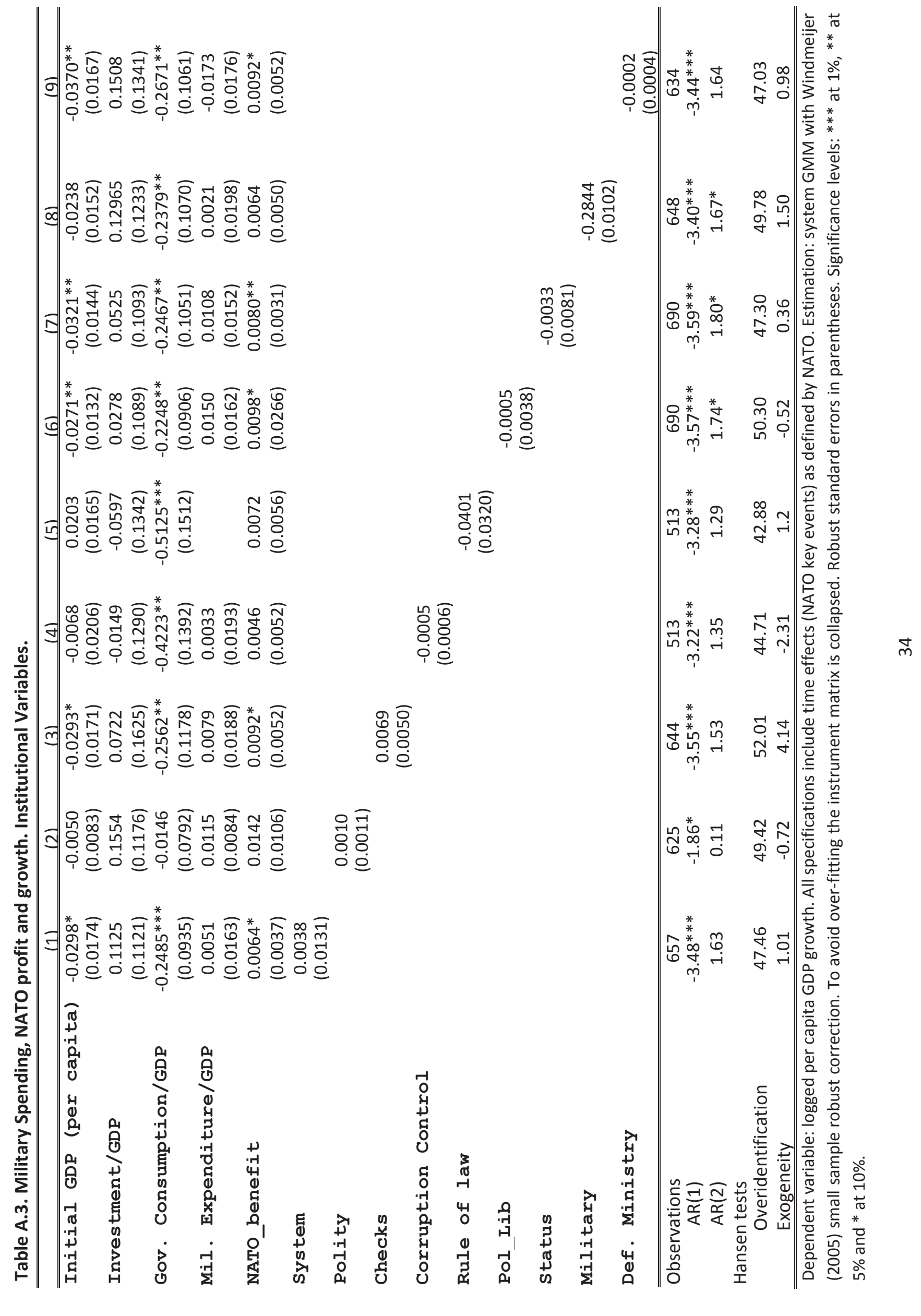




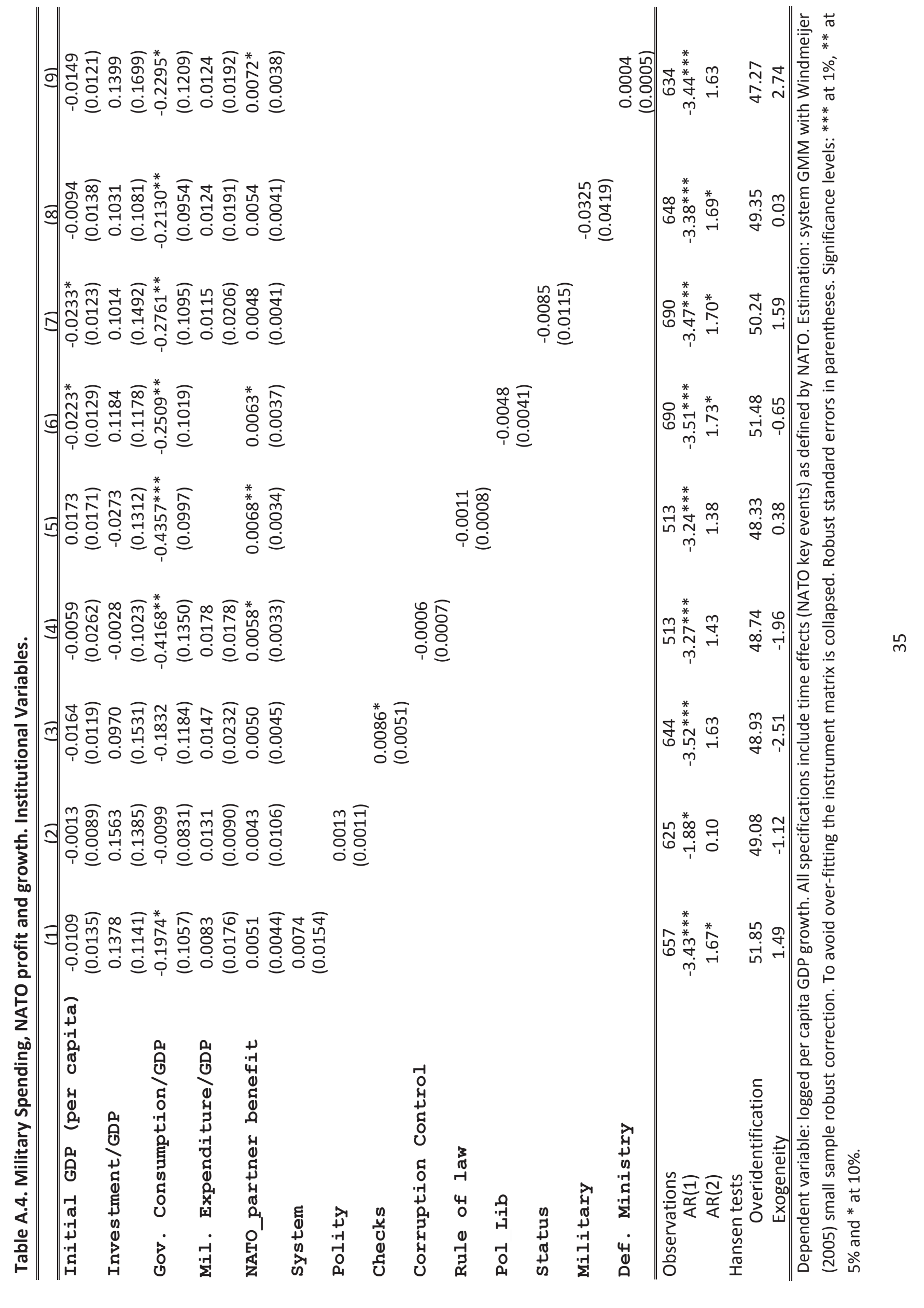

